Atmos. Chem. Phys., 17, 11803-11818, 2017

https://doi.org/10.5194/acp-17-11803-2017

(C) Author(s) 2017. This work is distributed under

the Creative Commons Attribution 3.0 License.

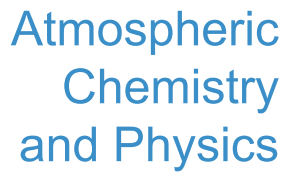

(c) (i)

\title{
Impacts of large-scale atmospheric circulation changes in winter on black carbon transport and deposition to the Arctic
}

\author{
Luca Pozzoli $^{1}$, Srdan Dobricic $^{1}$, Simone Russo $^{2}$, and Elisabetta Vignati ${ }^{1}$ \\ ${ }^{1}$ European Commission, Joint Research Centre (JRC), Directorate for Energy, Transport and Climate, Air and Climate Unit, \\ Ispra (VA), 21027, Italy \\ ${ }^{2}$ European Commission, Joint Research Centre (JRC), Directorate for Competences, Modelling, Indicators and Impact \\ Evaluation Unit, Ispra (VA), 21027, Italy
}

Correspondence to: Luca Pozzoli (luca.pozzoli@ec.europa.eu)

Received: 11 November 2016 - Discussion started: 22 December 2016

Revised: 12 May 2017 - Accepted: 17 August 2017 - Published: 6 October 2017

\begin{abstract}
Winter warming and sea-ice retreat observed in the Arctic in the last decades may be related to changes of largescale atmospheric circulation pattern, which may impact the transport of black carbon (BC) to the Arctic and its deposition on the sea ice, with possible feedbacks on the regional and global climate forcing. In this study we developed and applied a statistical algorithm, based on the maximum likelihood estimate approach, to determine how the changes of three large-scale weather patterns associated with increasing temperatures in winter and sea-ice retreat in the Arctic impact the transport of $\mathrm{BC}$ to the Arctic and its deposition. We found that two atmospheric patterns together determine a decreasing winter deposition trend of BC between 1980 and 2015 in the eastern Arctic while they increase BC deposition in the western Arctic. The increasing $\mathrm{BC}$ trend is mainly due to a pattern characterized by a high-pressure anomaly near Scandinavia favouring the transport in the lower troposphere of BC from Europe and North Atlantic directly into to the Arctic. Another pattern with a high-pressure anomaly over the Arctic and low-pressure anomaly over the North Atlantic Ocean has a smaller impact on BC deposition but determines an increasing $\mathrm{BC}$ atmospheric load over the entire Arctic Ocean with increasing BC concentrations in the upper troposphere. The results show that changes in atmospheric circulation due to polar atmospheric warming and reduced winter sea ice significantly impacted BC transport and deposition. The anthropogenic emission reductions applied in the last decades were, therefore, crucial to counterbalance the most likely trend of increasing BC pollution in the Arctic.
\end{abstract}

\section{Introduction}

The Arctic has warmed during the recent decades more strongly than other regions due to the polar amplification of the global warming signal (Serreze and Barry, 2011). Satellite observations show a decline in summer sea-ice extent since the late 1970s with a dramatic acceleration in the last decade. The sea ice is also characterized by increased fraction of thinner and younger sea ice, which is melting during the polar summer (Comiso, 2012; Kwok and Rothrock, 2009; Kwok, 2009; Maslanik et al., 2011; Rothrock et al., 2008). The rate of change of Arctic sea ice has increased so quickly over the last decades that the expression "new Arctic" has recently been coined (e.g. Döscher et al., 2014). During winter the sea-ice cover and concentration have changed significantly: a decreasing trend of sea-ice concentration in winter months, December-January-February (DJF), for the period 1979-2014 was observed by satellites over the Barents Sea at a rate of up to $20 \%$ per decade. Several studies investigated whether the varying winter sea-ice cover over the Barents Sea may further produce hemispheric-scale impacts in the atmosphere with changes in the large-scale atmospheric circulation (e.g. Barnes et al., 2014; Cohen et al., 2014; Deser et al., 2007; Mori et al., 2014; Overland and Wang, 2010; Petoukhov and Semenov, 2010; Screen et al., 2013; Semenov and Latif, 2015). Dobricic et al. (2016) analysed the atmospheric reanalysis of the past decades with a statistical approach, the independent component analysis (ICA), which has not been applied frequently in climate studies. ICA can be an efficient methodology to extract independent components (ICs), i.e. share the minimum information without the 
Gaussianity assumption (Hyvärinen and Oja, 2000). Dobricic et al. (2016) found that three independent atmospheric patterns, connected to the North Atlantic Oscillation (NAO), the Scandinavian blocking (SB) and the El Niño-Southern Oscillation (ENSO), are closely related to the ongoing hemispheric increase of near-surface temperature over the Barents Sea and may be related to the sea-ice cover shrinkage in this region. Thus, the changes in the ocean-sea ice-atmosphere energy fluxes may also impact the large-scale atmospheric circulation in the Northern Hemisphere, as well as the transport of atmospheric pollutants with possible feedbacks on the regional and global climate.

The aim of this study is to estimate how these changes in the large-scale circulation patterns of the Northern Hemisphere in winter could affect the transport of pollutants to the Arctic and in particular black carbon (BC). BC is a shortlived climate pollutant and thus one of the key targets for emission reduction strategies to mitigate the effects of climate change (Shindell et al., 2012). BC plays a key role in the Arctic climate system as it affects the Earth's radiative balance through different mechanisms. BC particles directly absorb solar radiation, and above a surface with high albedo, such as snow and sea ice, they warm the atmosphere inside the haze layer and at higher altitudes (Shaw and Stamnes, 1980). However, BC may also cool the Arctic climate due to surface dimming and decreased poleward heat flux caused by weakened latitudinal temperature gradient from BC heating of the upper troposphere (Flanner, 2013; Sand et al., 2013a, b; Shindell and Faluvegi, 2009). An indirect BC radiative forcing process is determined by its deposition on snow and ice, which can accelerate their melting. Hadley and Kirchstetter (2012) measured in laboratory how BC snow contamination can reduce snow albedo, with amplified $\mathrm{BC}$ radiative perturbation in larger snow grains size, which is also consistent with the parameterizations of $\mathrm{BC}$ and soot concentrations in snow included in climate models (Aoki et al., 2000; Flanner and Zender, 2006; Yasunari et al., 2011). Due to lower insolation in the Arctic during winter and early spring, $\mathrm{BC}$ exerts a negligible radiative forcing, but particles that deposit to snow and ice surfaces can re-emerge at the surface when melt commences in the summer (Conway et al., 1996), meaning that winter transport and deposition of $\mathrm{BC}$ is also affecting the Arctic climate.

Measurements show that the equivalent BC (EBC; filterbased absorption measurements of aerosol particles) surface concentrations in the Arctic, as well as those of other atmospheric pollutants, such as sulfate, are largest in winter and early spring, when the transport of pollutants from lower latitudes is more efficient and the removal processes slower (e.g. Eleftheriadis et al., 2009; Gong et al., 2010; Hirdman et al., 2010; Sharma et al., 2006, 2013). The extreme cold surface temperatures in the Arctic determine strong inversions that built the so-called polar dome (Klonecki, 2003; Stohl, 2006), characterized by stable air masses inside the dome and limited exchange between the boundary layer and the free tro- posphere, meaning that in the Arctic local sources of pollution are transported more efficiently. In contrast, the longrange transport of $\mathrm{BC}$ from lower latitudes may contribute more to the Arctic haze due to the significantly larger midlatitudes emission levels compared to those in the Arctic region (Sand et al., 2015). Another barrier which isolate the Arctic from the lower latitudes is the Arctic front (Barrie, 1986). Polluted air masses can reach the Arctic lower troposphere only if they are emitted in a sufficiently cold region located north of Arctic front, a situation which mainly occurs during winter in northern Eurasia. Pollution emitted south of the Arctic front is lifted above it, generally with cloud formation and scavenging of aerosol particles and deposition to the surface by precipitation. Pollutants emitted in North America and East Asia can reach the Arctic mainly through this pathway (Stohl, 2006). As a result, the main contribution to winter BC surface concentrations and deposition in the Arctic originated from northern Eurasia (Hirdman et al., 2010). The BC concentration and deposition vary considerably on interannual timescale, and large-scale atmospheric circulation processes can favour or reduce the transport of pollutants from the main source regions (North America and Eurasia) toward the Arctic. Hirdman et al. (2010) analysed the longterm trends of EBC and sulfate measured at three stations in the Arctic. They found that EBC surface concentrations decreased at two Arctic stations, Alert (Canada) and Zeppelin (Svalbard islands, Norway), while there is no trend detectable at Barrow (Alaska). Analysing the atmospheric back trajectories at the three stations, they concluded that the observed decreasing trends are mainly driven by changes in the emissions, while the impact of atmospheric circulation can only explain a minor fraction of the downward trend. They found significant correlations between the North Atlantic Oscillation index (NAOI) and air masses from North America and northern Eurasia at both Alert and Barrow but not for the station at Zeppelin. However, full understanding of how the transport changes related to large-scale circulation patterns, such as the NAO, impact the BC concentrations and deposition to the Arctic has not yet been established.

In this study we apply a statistical methodology, based on a Bayesian approach, to investigate the relationships between large-scale atmospheric circulation patterns and the longrange atmospheric transport of air pollutants to the Arctic in recent decades. We estimate the most likely BC distribution associated with large-scale atmospheric patterns which can approximate the near-surface temperature trend in the Arctic, both spatially and temporally, of two atmospheric reanalysis of the past decades (Dobricic et al., 2016). The distributions of BC surface concentration, total column and deposition fluxes were taken from a hindcast simulation of tropospheric chemistry composition for the period 1980-2005. Three different BC simulations are analysed, one with changing anthropogenic emissions for the entire period and two with fixed anthropogenic emissions from the years 1980 and 2000. With this methodology we aim to quantify the trends and in- 
terannual variability of BC surface concentrations, load and deposition in the Arctic associated with winter large-scale atmospheric circulation changes occurred in the last decades.

\section{Methods and data}

In the following sections we will first describe the statistical method (Sect. 2.1) and the data used for the analysis. Section 2.2 provides a short introduction to the large-scale atmospheric patterns identified by Dobricic et al. (2016), which mainly contribute to the winter polar warming of the last decades. Section 2.3 describes the data used to estimate the maximum likelihood distribution of $\mathrm{BC}$ concentration and deposition associated with the specific atmospheric patterns.

\subsection{Maximum likelihood estimate (MLE) of atmospheric pollutants}

The MLE of the distribution of a pollutant in the atmosphere associated with a specific atmospheric pattern may be derived starting from Bayes' theorem. The probability, $p(\boldsymbol{c} \mid \boldsymbol{a})$, of an unknown joint distribution of an atmospheric pollutant and corresponding atmospheric state, $\boldsymbol{c}$, given a specific atmospheric pattern, $\boldsymbol{a}$, may be expressed as

$p(\boldsymbol{c} \mid \boldsymbol{a}) \cong p(\boldsymbol{a} \mid \boldsymbol{c}) p(\boldsymbol{c})$,

where $p(\boldsymbol{c})$ is the priori probability of coupled pollutant distribution (e.g. atmospheric concentrations, surface deposition or atmospheric burden) coupled with corresponding atmospheric conditions, and $p(\boldsymbol{a} \mid \boldsymbol{c})$ is the probability that a certain atmospheric pattern (e.g. surface pressure, geopotential height, wind speed) is associated with the atmospheric state coupled with pollutant distributions. The prior probability, $p(\boldsymbol{c})$, can be estimated, for example, by using chemistryclimate model simulations of the past or future atmospheric physical parameters and the corresponding coupled chemical compositions. In order to simplify the mathematical solution of the problem we assume that the two distributions, $p(\boldsymbol{a} \mid \boldsymbol{c})$ and $p(\boldsymbol{c})$, are approximately Gaussian, meaning that their product, $p(\boldsymbol{c} \mid \boldsymbol{a})$, will also be Gaussian. This assumption is supported by the central limit theorem, which tells us that the distribution produced by several processes with non-Gaussian distributions should appear closer to a Gaussian distribution (e.g. Hyvärinen and Oja, 2000). Thus it is possible to estimate the probability of a pollutant distribution for any atmospheric pattern $\boldsymbol{a}_{k}$, which can be taken from an independent atmospheric model simulation or a specific large-scale atmospheric pattern, like the ENSO or the NAO. Equation (1) becomes

$$
\begin{aligned}
& p\left(\boldsymbol{c} \mid \boldsymbol{a}_{k}\right)=\text { const } \times \\
& \exp \left\{-\frac{1}{2}\left[\boldsymbol{a}_{k}-H(\boldsymbol{c})\right]^{T} \boldsymbol{D}^{-1}\left[\boldsymbol{a}_{k}-H(\boldsymbol{c})\right]-\frac{1}{2} \boldsymbol{c}^{T} \boldsymbol{C}^{-1} \boldsymbol{c}\right\},
\end{aligned}
$$

where $H(\boldsymbol{c})$ is an operator which interpolates the coupled atmospheric states, $\boldsymbol{c}$, on the model grid of the atmospheric pattern, $\boldsymbol{a}_{k}$.

The MLE of $p\left(\boldsymbol{c} \mid \boldsymbol{a}_{k}\right)$ is the one with the minimum absolute value of the argument of the exponential function in Eq. (2), which is the minimum of the cost function $J$ :

$J=\frac{1}{2}\left[\boldsymbol{a}_{k}-H(\boldsymbol{c})\right]^{T} \mathbf{D}^{-1}\left[\boldsymbol{a}_{k}-H(\boldsymbol{c})\right]+\frac{1}{2} \boldsymbol{c}^{T} \mathbf{C}^{-1} \boldsymbol{c}$.

Assuming that the mapping $H$ is linear (e.g. a bilinear interpolation, $H(\boldsymbol{c})=\mathbf{H} \boldsymbol{c}), J$ becomes a quadratic function with a single minimum which may be estimated by a linear minimizer. The numerical stability may be further increased by defining a control subspace $\boldsymbol{z}=\mathbf{Z}^{+} \boldsymbol{c}$, where $\mathbf{Z}$ is a square root of $\mathbf{C}$ and the superscript + indicates the generalized inverse. The cost function becomes

$J=\frac{1}{2}\left[\boldsymbol{a}_{k}-\mathbf{H Z} \boldsymbol{z}\right]^{T} \mathbf{D}^{-1}\left[\boldsymbol{a}_{k}-\mathbf{H Z} \boldsymbol{z}\right]+\frac{1}{2} z^{T} z$.

After finding $z$, the most likelihood coupled anomaly is obtained from

$c=\mathbf{Z} z$

The cost function $J$ is minimized using the quasiNewtonian limited memory Broyden-Fletcher-GoldfarbShanno (L-BFGS) minimizer (Byrd et al., 1995). It is assumed that $\mathbf{D}$ is a diagonal matrix and elements along the diagonal have equal variance divided by the area of each grid point. The atmospheric patterns $\boldsymbol{a}_{k}$, for which we estimate the maximum likelihood distribution of atmospheric pollutants, are those previously described by Dobricic et al. (2016) and briefly described in Sect. 2.2. Matrix $\mathbf{C}$ is estimated from coupled anomalies of a multi-year simulation with a coupled atmosphere-chemistry model, described in more details in Sect. 2.3. Coupled anomalies contain both the atmospheric physical parameters and pollution concentrations. In order to filter out statistically insignificant relationships, the covariance matrix of anomalies is approximated by forming the empirical orthogonal function (EOF) decomposition and by maintaining only EOFs with major eigenvalues. The minimum of the cost function $J$ is found for each winter month (DJF) and for each atmospheric pattern $\boldsymbol{a}_{k}$, separately.

\subsection{Atmospheric patterns}

Dobricic et al. (2016) performed an ICA of atmospheric reanalysis data finding a link between the increasing trend of near-surface temperature in the Arctic during winter (DJF) and three atmospheric patterns. Hannachi et al. (2009) first proposed applying the ICA instead of the commonly used EOF in climate studies, showing that ICA may be explained by a rotation of EOFs. The major difference between the two estimates is that ICA does not assume the Gaussian distributions of event probabilities. This property ensures that components are truly independent and not just uncorrelated; 
however, it is not possible to determine the order of the ICs. In Dobricic et al. (2016) the FastICA algorithm by Hyvärinen and Oja (2000) was applied to extract independent atmospheric components in winter during the period 1980-2015. The ICA algorithm finds the best approximation of a matrix $\mathbf{X}$ containing rows of temporal anomalies in the physical space:

$\mathbf{X} \cong \mathbf{A S}$,

where the columns of matrix A represent spatially varying intensities and the rows of the orthogonal matrix $\mathbf{S}$ are the temporally varying independent components. Matrix $\mathbf{A}$ is full rank, but its columns are not orthogonal. This means that there may be overlapping spatial features in different columns of A. Details on implementing ICA for largescale atmospheric processes may be found in Dobricic et al. (2016); here we introduce the main results of their study, which are used as input for our analysis. A set of three independent large-scale atmospheric structures were found, with significant linear trends and together approximating the spatial variability of near-surface temperature trend during winter, as well as atmospheric anomalies of wind intensity, temperature and geopotential height at different pressure levels from surface up to 10 mbar. Figure 1 shows the spatial distribution of the trends from 1980 to 2015 averaged over the three winter months for near-surface temperature at $1000 \mathrm{mbar}$ (T1000) and geopotential height at $850 \mathrm{mbar}$ (H850). The spatial distribution of the three ICs with statistically significant trends were named by visually recognizing their similarity to well-known large-scale weather patterns: the NAO, SB and ENSO. In this paper we will refer to the IC patterns as $\mathrm{IC}_{\mathrm{NAO}}, \mathrm{IC}_{\mathrm{SB}}$ and $\mathrm{IC}_{\mathrm{ENSO}}$ to avoid confusion with the NAO, SB and ENSO indices. The mean winter $\mathrm{H} 850$ trend of $\mathrm{IC}_{\mathrm{NAO}}$ (Fig. 1a) with increasing geopotential height over the Arctic and decreasing in the Atlantic Ocean near the Azores clearly appears as a tendency toward the negative phase of the NAO. T1000 increases over the Arctic with maximum over western Greenland, the Canadian archipelago and the Barents Sea, while at the same time it decreases over northern Europe and Siberia (Fig. 1d). The $\mathrm{IC}_{\mathrm{SB}}$ trend shows an increasing geopotential height over Scandinavia and north-western Siberia, which indicates a prevailing anticyclonic anomaly over the area, bringing warm air from Europe to the Arctic and cold air from the Arctic to Eurasia (T1000 in Fig. 1e). As shown in Fig. 1c and f, IC ENSO has a small T1000 trend over the Arctic, compared to the other two IC patterns. The reanalysis trends of T1000 and H850 are approximated well by summing the three ICs; all dominant features are captured both spatially and temporally, in particular the prominent dipole between the strong warming in the Arctic and cooling over Siberia (Dobricic et al., 2016). Consistent results were obtained using two different atmospheric reanalysis (Dobricic et al. 2016), the National Center for Environmental Prediction (NCEP; Kalnay et al., 1996) and ERA-Interim (Dee et al., 2011) from the European Centre for Medium-Range Weather Forecasts (ECMWF). In our study we will estimate the maximum likelihood distribution of $\mathrm{BC}$ atmospheric concentration, load and deposition associated with the $\mathrm{IC}_{\mathrm{NAO}}$ and $\mathrm{IC}_{\mathrm{SB}}$ atmospheric patterns found in Dobricic et al. (2016). We do not discuss the third atmospheric pattern, the $\mathrm{IC}_{\mathrm{ENSO}}$, which showed weaker connection to the changes seen in near-surface temperature and geopotential height in the Arctic region.

\subsection{Atmospheric chemical composition}

We used winter monthly mean anomalies (DJF) of BC concentrations and surface deposition fluxes of the period 19802005 from hindcast simulations of the fully coupled aerosolchemistry-climate model, ECHAM5-HAMMOZ (Pozzoli et al., 2011), which is composed of the general circulation model ECHAM5 (Roeckner et al., 2003), the tropospheric chemistry and aerosol module HAMMOZ (Pozzoli et al., 2008a). The horizontal resolution of the simulations is about $2.8^{\circ} \times 2.8^{\circ}$, with 31 vertical levels from the surface up to $10 \mathrm{hPa}$. The simulation was forced by nudging the reanalysis meteorological fields from the ECMWF ERA-40 reanalysis (Uppala et al., 2005) from year 1980 to 2000 and the operational analyses (IFS cycle-32r2) was used until year 2005. The dry deposition scheme of aerosol particles follows Ganzeveld and Lelieveld (1995), while in-cloud and belowcloud scavenging follows the scheme described by Stier et al. (2005). The anthropogenic emissions of $\mathrm{CO}, \mathrm{NO}_{x}$ and volatile organic carbons for the period 1980-2000 are taken from the RETRO inventory (Endresen et al., 2003; Schultz et al., 2007, 2008). The AeroCom hindcast aerosol emission inventory (Diehl et al., 2012) was used for the annual total anthropogenic emissions of primary $\mathrm{BC}$, organic carbon aerosols and sulfur dioxide $\left(\mathrm{SO}_{2}\right)$. The $\mathrm{BC}$ anthropogenic emissions remained almost constant globally during the simulated period (1980-2005), at $4.9 \mathrm{Tg} \mathrm{yr}^{-1}$, but large changes occurred in North America, Europe, Former Soviet Union (FSU) and East Asia (Supplement Fig. S1a, c). Most of the anthropogenic $\mathrm{BC}$ is emitted between 30 and $60^{\circ} \mathrm{N}$ and decreased after the $1990 \mathrm{~s}$ from about 3 to about $2.6 \mathrm{Tg} \mathrm{yr}^{-1}$ after 2000. Above $60^{\circ} \mathrm{N} \mathrm{BC}$ anthropogenic emissions are a small fraction of the total and decreased from 100 to $30 \mathrm{Gg} \mathrm{yr}^{-1}$. The simulation also includes interannual varying biomass burning emissions, from tropical savannah burning, deforestation fires and mid- and high-latitude forest fires published by Schultz et al. (2008). BC biomass burning emissions range between 10 and $170 \mathrm{Gg} \mathrm{yr}^{-1}$ above $60^{\circ} \mathrm{N}$ and between 35 and $460 \mathrm{Gg} \mathrm{yr}^{-1}$ at mid-latitudes, with peak years connected to interannual meteorological variability (Fig. S1b, d).

The model has been extensively evaluated in previous studies by comparing simulated chemical concentrations and physical parameters to observations (Auvray et al., 2007; Pausata et al., 2012, 2013; Pozzoli et al., 2008a, b; Rast et 
(a) $I_{\text {NAO }}(H 850)$

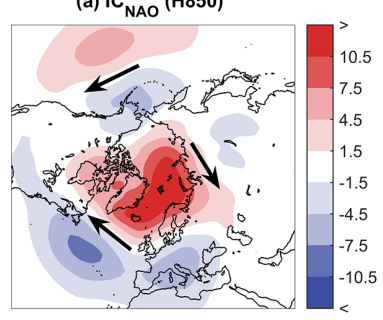

(d) $I_{\text {NAO }}(T 1000)$

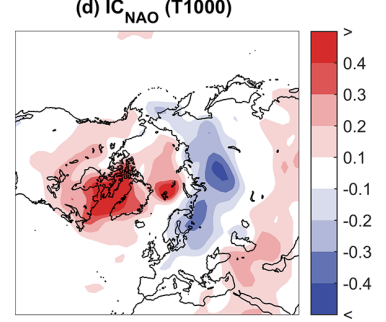

(b) $\mathrm{IC}_{\mathrm{SB}}(\mathrm{H} 850)$

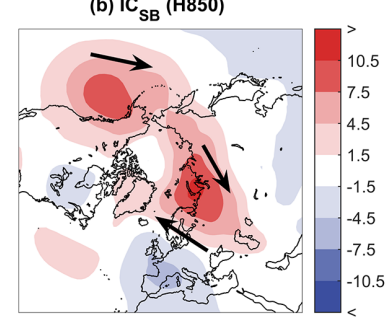

(e) $\mathrm{IC}_{\mathrm{SB}}(\mathrm{T} 1000)$

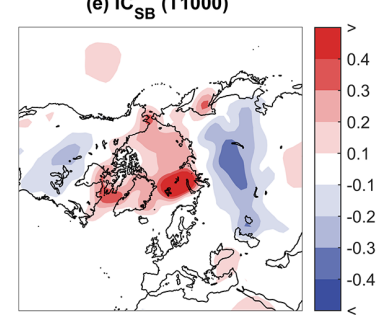

(c) IC ${ }_{\text {ENSO }}$ (H850)

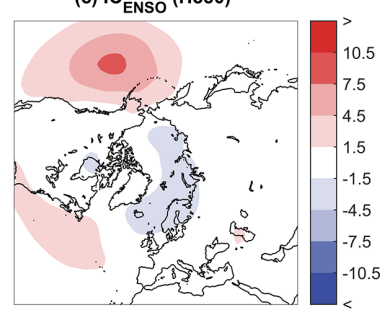

(f) IC ENSO (T1000)

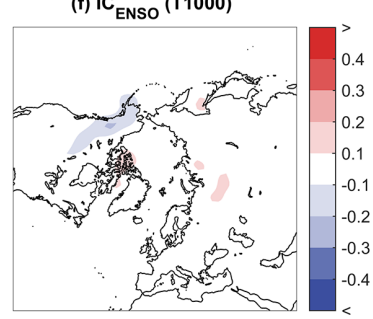

Figure 1. Winter trends (1980-2015) of geopotential height at $850 \mathrm{mbar}\left(\mathrm{H} 850, \mathrm{~m} \mathrm{yr}^{-1}\right.$, a-c) and near-surface temperature at $1000 \mathrm{mbar}$

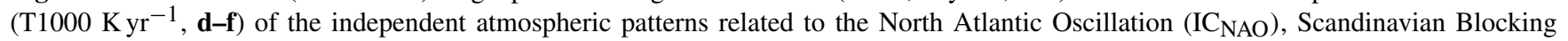
$\left(\mathrm{IC}_{\mathrm{SB}}\right)$ and $\mathrm{El}$ Niño-Southern Oscillation $\left(\mathrm{IC}_{\mathrm{ENSO}}\right)$. The arrows provide a qualitative representation of the circulation paths tendencies associated with the (a) $\mathrm{IC}_{\mathrm{NAO}}$ and (b) $\mathrm{IC}_{\mathrm{SB}}$ independent component patterns.

al., 2014; Stier et al., 2005; Bourgeois and Bey, 2011) and within model intercomparison studies (Kim et al., 2014; Pan et al., 2015; Tsigaridis et al., 2014). As shown by Bourgeois and Bey (2011), ECHAM5-HAMMOZ largely underestimates $\mathrm{BC}$ concentrations over the Arctic, both near the surface and in the atmospheric column. Compared to the BC measurements from SP2 instrument (Moteki and Kondo, 2007; Schwarz et al., 2006) of the Arctic Research of the Composition of the Troposphere from Aircraft and Satellites (ARCTAS; Jacob et al., 2010), the simulated BC concentrations show a mean absolute bias in the troposphere of $95 \%$ in spring, while in summer the BC is well simulated in the upper troposphere and overestimated by $50 \%$ near the surface. Bourgeois and Bey (2011) identified the wet scavenging of aerosol particles as one of the main processes responsible for model bias in winter; a model simulation with revisited wet scavenging coefficients from Henning et al. (2004) considerably improved the simulated BC concentrations in the troposphere in winter, reducing the mean absolute bias to $38 \%$. The large bias of simulated BC and EBC concentrations in the Arctic is a known issue, shared with several global climate and chemical transport models (Eckhardt et al., 2015; Sand et al., 2017). Qi et al. (2017) estimated that the Wegener-Bergeron-Findeisen process in mixed-phase clouds increases $\mathrm{BC}$ in the atmosphere by 25 to $70 \%$ by reducing wet scavenging efficiency. Other factors which may improve the simulated BC distribution in the Arctic are dry deposition velocities calculated with resistancein-series method over all surfaces (ocean, snow/ice) and improved BC flaring emissions (Qi et al., 2017; Stohl et al.,
2013). Jiao et al. (2014) show that BC concentrations in snow are poorly correlated with measurements, and a large spread is found among 25 model simulations, with $\mathrm{BC}$ lifetime in the Arctic ranging from about 4 to 23 days, implying large differences in local BC deposition efficiency. In this study we will focus on the impacts of large-scale atmospheric circulation trends on the transport of $\mathrm{BC}$ to the Arctic through a novel statistical methodology, assuming that underestimating BC concentrations does not significantly affect the spatial distribution of the trends. Three different simulations of the period 1980-2005 are available for our analysis: a reference simulation with annually varying anthropogenic emissions (thereinafter named REF) and two additional simulations with anthropogenic emissions kept constant for the entire period (1980-2005) at the levels of the years 1980 and 2000 (thereinafter named FIX1980 and FIX2000). These three simulations will provide a preliminary estimate of the uncertainty of our findings due to the different levels and their geographical distribution of anthropogenic emissions used in the different simulations. Other model simulations may be analysed in the future to quantify the uncertainty associated with different chemical mechanisms and physical parameterizations.

\section{Results}

In this study we will focus on the trends of $\mathrm{BC}$ transport patterns from northern hemispheric mid-latitudes towards the Arctic during winter months. Trends are calculated by the Sen-Kendall method (Sen, 1968). The statistical significance 
for all trends is set to the 0.05 level and is estimated by the Mann-Kendall test (Mann, 1945). Areas with significant trends are marked with small grey dots in the figures except for the trends of atmospheric patterns and maximum likelihood estimates of BC that have spatially uniform slopes. We first analyse the trends as simulated by a coupled chemistryclimate model under three different anthropogenic emission scenarios (Sect. 3.1). This first analysis will provide an estimate of the relative contribution of anthropogenic emissions and natural variability to the transport of $\mathrm{BC}$ toward the Arctic. In the second part, through the statistical method described in Sect. 2, the trend associated with the natural variability are further decoupled into the contributions from the northern hemispheric large-scale atmospheric weather patterns (Sect. 3.2), which were found to be associated with the observed near-surface Arctic warming and sea-ice retreat (Dobricic et al., 2016). In Sect. 3.3 we will illustrate the total trends due to the three independent atmospheric components and their impact on the interannual variability of BC wet deposition and load over the Arctic. The statistical method was applied to a combination of different datasets in order to analyse the spread of different solutions obtained using two different atmospheric reanalysis and three different chemistry-climate model simulations and for different time periods (Sect. 3.4).

\subsection{Total trends of $\mathrm{BC}$ simulated by ECHAM5-HAMMOZ}

Figure 2 shows the 26-year (1980-2005) trends of BC dry and wet deposition, surface concentration and vertically integrated atmospheric load over to the Arctic for the REF simulation, which includes the effects of both annually varying anthropogenic emissions and interannual meteorological variability. Decreasing and statistically significant trends are simulated over almost the entire Arctic for dry and wet deposition, as well as surface concentrations. The main reductions occurred in the eastern part of the Arctic, from the Scandinavian Peninsula along almost the entire Russian northern coastline, indicating the important role of the emission reductions occurred in the last decades in Europe and Russia. Previous studies also showed that the main transport pathway of air pollution to the Arctic in winter originates from the Eurasian continent (Sharma et al., 2013; Stohl, 2006). Nevertheless, it is interesting to note that an increasing trend of BC burden is simulated over the entire western Arctic and also part of Eastern Siberia. A possible explanation for this result can be found in the increasing anthropogenic emissions in East Asia in the last decades (Fig. S1). The long-range transport of aerosol particles from East Asia to the Arctic occurs in the middle and upper Arctic troposphere, as the warm air masses originated south of the Arctic front are lifted above and affect the BC burden more than surface concentration and deposition due to slow mixing with surface atmospheric layers. In contrast, the emissions in Eurasia can be often lo- cated north of the Arctic front during winter and therefore $\mathrm{BC}$ is transported to the lower troposphere, affecting more surface concentrations and deposition (AMAP, 2015). Similar results were found by Sharma et al. (2013), who estimated a contribution of East Asia that was 3 times larger than the BC burden in the Arctic between 1990 and 2005; in the same period the contribution to $\mathrm{BC}$ burden and surface concentrations from the FSU declined by 50 and $70 \%$, respectively. The REF, FIX2000 and FIX1980 simulations are driven by the same atmospheric reanalysis and annually varying biomass burning emissions. The interannual meteorological variability of the last decades combined with constant anthropogenic emissions (FIX2000 in Fig. 3 and FIX1980 in Fig. S2) determined a significant increasing trend of BC dry deposition and surface concentrations over the Arctic, while BC wet deposition increased over the Canadian Archipelago and Greenland. Both FIX2000 and FIX1980 simulations show similar patterns, with differences due to the changing geographical distribution of anthropogenic emissions, larger in Europe and North America in 1980 and predominant in East Asia in 2000. Neither FIX2000 nor FIX1980 shows a significant trend in BC burden over the Arctic (Figs. 2d and S2d), which further confirms the role of anthropogenic emissions in East Asia that affect the transport of air pollution at higher altitudes to the Arctic. In some regions, like the Canadian Archipelago and the western Arctic Ocean, the changes in $\mathrm{BC}$ trends due to meteorology and natural variability contribute as much as the changes due to anthropogenic emissions. In the next sections we will further decompose the transport pathways of air pollution to the Arctic associated with the main large-scale atmospheric circulation patterns, which describe the trend of the warming amplification in the polar region and which have characterized the changing climate of the Northern Hemisphere of the last decades.

\subsection{Trends of $\mathrm{BC}$ due to atmospheric circulation changes}

Three large-scale atmospheric patterns were identified by Dobricic et al. (2016) as closely related to the near-surface warming trend in the polar region during winter months (DJF). Two of them, $\mathrm{IC}_{\mathrm{NAO}}$ and $\mathrm{IC}_{\mathrm{SB}}$, showed statistically significant trends of surface temperature and geopotential height over the Arctic during the last 36 years (1980-2015), and together could reproduce well the spatial and temporal distribution of the trends found in two atmospheric reanalysis (NCEP and ECMWF ERA-Interim; Sect. 2.2) In this section we limit our analysis to trends of MLE of BC wet deposition, concentration and load from the FIX2000 simulation and for the longest period available for the construction of coupled anomalies, 26 years (1980-2005). The trends of BC deposition and load are obtained by multiplying the MLE of the $\mathrm{BC}$ field by the trend of the associated atmospheric pattern, from the ICA previously performed by Dobricic et al. (2016). We will not discuss the trends of $\mathrm{BC}$ dry deposition as in the 
(a) Wet dep. [kg yr-1] REF

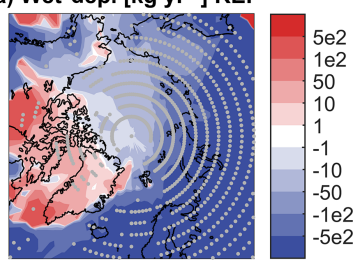

(c) Srf. conc. $\left[10^{-3} \mathrm{ng} \mathrm{kg}^{-1} \mathrm{yr}^{-1}\right] \mathrm{REF}$

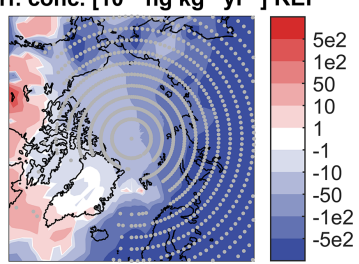

(d) Load $\left[10^{-2} \mathrm{~kg} \mathrm{yr}^{-1}\right]$ REF

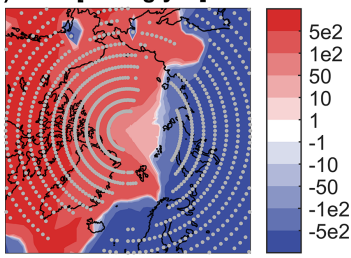

Figure 2. Winter (DJF) trends (1980-2005) of BC wet deposition (a), dry deposition (b), surface concentration (d) and total load (d) for the ECHAM5-HAMMOZ REF simulation. Grey dots represent the grid points with trend significant at $5 \%$ level.

ECHAM5-HAMMOZ simulations it is only a small fraction of the total trend of $\mathrm{BC}$ deposition in the Arctic (Figs. 1b, 2b and $\mathrm{S} 2 \mathrm{~b}$ ).

Figure 1 shows the trends of geopotential height at 850 mbar associated with $\mathrm{IC}_{\mathrm{NAO}}$ and $\mathrm{IC}_{\mathrm{SB}}$ patterns estimated by the ICA of NCEP atmospheric reanalysis data by Dobricic et al. (2016), while the arrows visually indicate how these trends may favour certain pollution transport pathways. We can expect that due to the different dynamical structures of $\mathrm{IC}_{\mathrm{NAO}}$ and $\mathrm{IC}_{\mathrm{SB}}$ they will differently impact the transport and deposition of pollutants from emission areas in the middle latitudes and their deposition rate once they reach the Arctic atmosphere. The tendency of $\mathrm{IC}_{\mathrm{NAO}}$ toward the negative phase of the NAO (Fig. 1a) forms an anticyclonic anomaly over the large part of the Arctic Ocean and a cyclonic anomaly in the North Atlantic Ocean. The intensity of westerly winds is decreased in the lower troposphere, with lower transport of pollution from North America across the Atlantic Ocean. In contrast, the $\mathrm{IC}_{\mathrm{NAO}}$ slightly increases the transport of pollution from north-western America towards the Arctic Ocean. This is also consistent with the results of Hirdman et al. (2010), which found significant correlations between the NAO index and EBC surface concentrations in Alert and Barrow, both in the western Arctic, with decreasing impact from northern Eurasia and increasing impact from North America. Consistent with the circulation pathways described in Fig. 1a, the MLEs of BC wet deposition trends related to $\mathrm{IC}_{\mathrm{NAO}}$ (Fig. 4) show a decreasing trend north of the Eurasian coast and an increasing trend north of America and Greenland. A correlation between the negative phase of the NAO and increasing precipitations and snow accumulation over western Greenland was also found by previous studies (e.g. Appenzeller et al., 1998; Mosley-Thompson et

(a) Wet dep. [kg yr-1] FIX2000

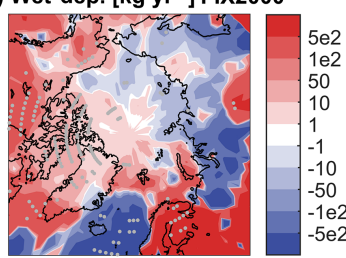

(c) Srf. conc. $\left[10^{-3} \mathrm{ng} \mathrm{kg}^{-1} \mathrm{yr}^{-1}\right]$ FIX2000

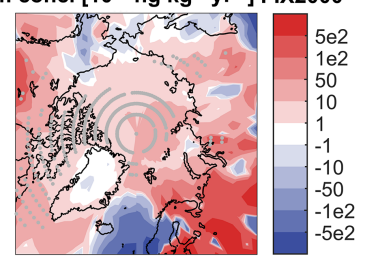

(b) Dry dep. $\left[10^{-3} \mathrm{~kg} \mathrm{yr}^{-1}\right]$ FIX2000

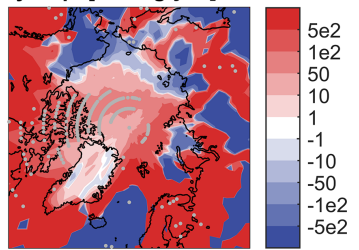

(d) Load $\left[10^{-2} \mathrm{~kg} \mathrm{yr}^{-1}\right]$ FIX2000

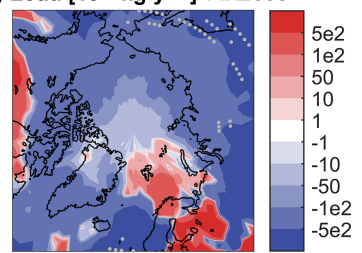

Figure 3. Winter (DJF) trends (1980-2005) of BC wet deposition (a), dry deposition (b), surface concentration (c) and total load (d) for the ECHAM5-HAMMOZ FIX2000 simulation. Grey dots represent the grid points with trend significant at $5 \%$ level.

al., 2005). The BC load has a positive trend over most of the Arctic Ocean, Greenland and the Canadian Archipelago, which may be associated with the dipole of pressure anomalies over the Pacific Ocean that also favours the export of polluted air masses from East Asia into North America and the Arctic (Fig. 1a). Sharma et al. (2013) previously showed that the contribution of East Asian BC emissions in the Arctic above $200 \mathrm{mb}$ is the largest. The trends of average BC concentrations at different altitudes above $60^{\circ} \mathrm{N}$ at four different longitudinal portions (quadrants) of the Arctic $\left(0-90^{\circ} \mathrm{E}\right.$; $\left.90-180^{\circ} \mathrm{E} ; 180-90^{\circ} \mathrm{W} ; 90-0^{\circ} \mathrm{W}\right)$ are shown in Fig. 5. In all four Arctic quadrants an increasing trend of $\mathrm{BC}$ concentrations is estimated at an altitude of about $10 \mathrm{~km}$, near the tropopause. Above the tropopause a shift in the vertical profile of $\mathrm{BC}$ concentration is observed, with a decreasing trend between the tropopause and $15 \mathrm{~km}$ and an increasing trend above $15 \mathrm{~km}$ and $70^{\circ} \mathrm{N}$. As shown in Dobricic et al. (2016), the evolution of the $\mathrm{IC}_{\mathrm{NAO}}$ pattern from December to February indicates a weakening of the stratospheric vortex linking the tropospheric perturbation with the stratosphere, in agreement with findings by Feldstein and Lee (2014). There is an enhanced mixing anomaly between the troposphere and the stratosphere indicated by increased $\mathrm{BC}$ concentrations above and decreased below the tropopause. Near the surface the $\mathrm{IC}_{\mathrm{NAO}}$ has a small impact on $\mathrm{BC}$ concentrations with few differences in the four Arctic quadrants. Only between 0 and $90^{\circ} \mathrm{E}$ is there a small increasing trend above $70^{\circ} \mathrm{N}$, while between 90 and $0^{\circ} \mathrm{E}$ the $\mathrm{BC}$ concentrations increase only below $70^{\circ} \mathrm{N}$.

The $\mathrm{IC}_{\mathrm{SB}}$ pattern (Fig. 1b), similar to Scandinavia blocking, consists of an anticyclonic centre near Scandinavia and weaker centres of opposite sign over south-western Europe and Siberia/Mongolia. In this case advection changes in the 


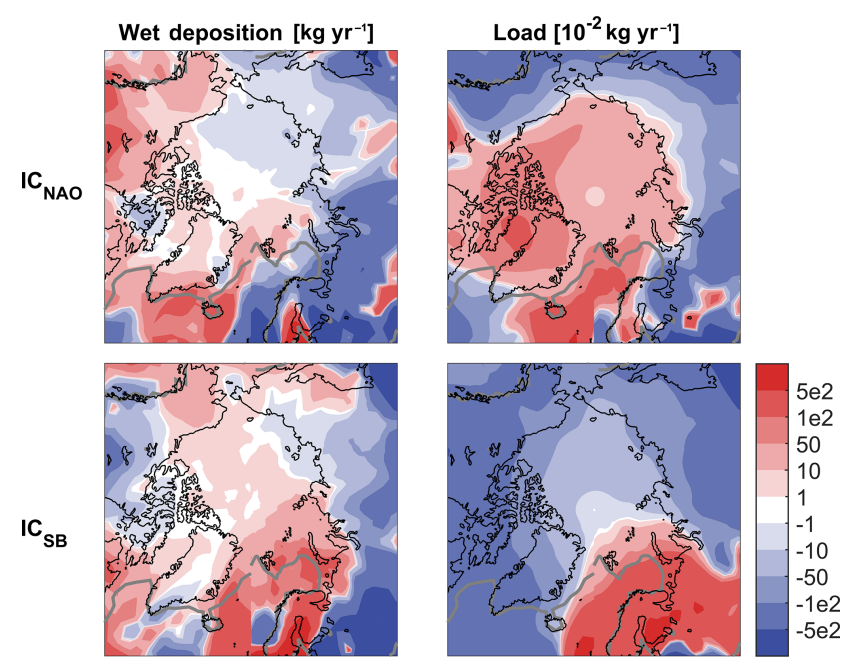

Figure 4. Winter (DJF) trends (1980-2015) of maximum likelihood estimates (MLEs) of BC wet deposition $\left(\mathrm{kg} \mathrm{yr}^{-1}\right)$ and load $\left(\mathrm{kg} \times 10^{-2} \mathrm{yr}^{-1}\right)$ associated with $\mathrm{IC}_{\mathrm{NAO}}$ and $\mathrm{IC}_{\mathrm{SB}}$. The grey line represents the mean winter sea ice and snow cover larger than $50 \%$ from 1980 to now. NAO and SB trends are both significant at $5 \%$ level.

lower troposphere indicated by the arrows favour the larger transport of pollutants from Europe directly to the sea-icecovered areas of the Arctic Ocean, while due to the southward position of the anticyclonic anomaly the vertical stability over the Arctic is not changed significantly. The large high-pressure anomaly over the north Pacific Ocean decreases the Asian influence on the Arctic. In a dynamically consistent way it advects the warm air from the south to the Barents Sea and the cold air from the Arctic into Siberia. This circulation pattern results in an increased transport of pollution from central Europe directly to the Barents Sea and the Arctic, while the transport from Siberia to the Arctic is suppressed. All estimates of the deposition of $\mathrm{BC}$ related to $\mathrm{IC}_{\mathrm{SB}}$ show a strong positive trend that extends from the Fram Strait, the Barents and Kara seas to the central part of the Arctic Ocean (Fig. 4). The positive trend of the load spreads over the Norwegian Sea and Scandinavia and indicates the northward advection of the pollution from Europe towards the Arctic Ocean. The relationship between $\mathrm{IC}_{\mathrm{SB}}$ deposition and load trends and the trend of the anticyclonic circulation over Scandinavia is especially evident in February (not shown) when the Scandinavian anticyclone trend is the most pronounced (Dobricic et al., 2016). The vertical structure of the estimated BC concentration trend (Fig. 6) shows that in these conditions the maximum concentration trend is located in the lower troposphere below $3 \mathrm{~km}$ and mainly in the first quadrant of the Arctic $\left(0-90^{\circ} \mathrm{E}\right)$. A strong increasing trend extends from mid-latitudes up to $90^{\circ} \mathrm{N}$ near the surface. In contrast, a negative trend is observed over the entire Arctic near the tropopause and above. The $\mathrm{IC}_{\mathrm{SB}}$ pattern is associated with a negative phase of the ENSO (La Niña), with

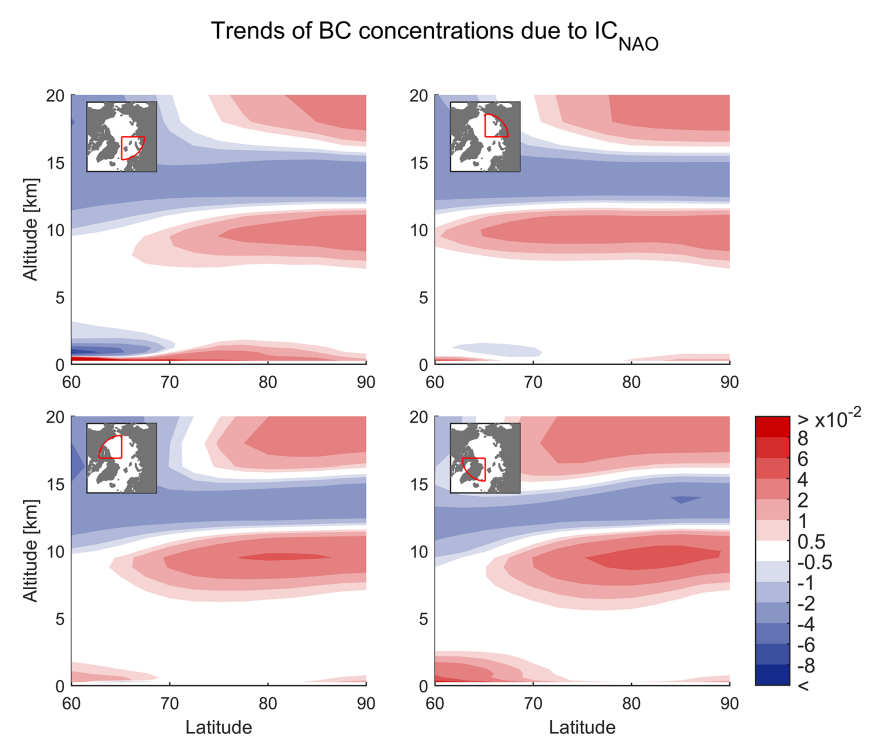

Figure 5. Winter (DJF) trends (1980-2015) of maximum likelihood estimates of $\mathrm{BC}$ concentrations $\left(\mathrm{ng} \mathrm{kg}^{-1} \mathrm{yr}^{-1}\right)$ associated with $\mathrm{IC}_{\mathrm{NAO}}$ circulation pattern. $\mathrm{BC}$ concentrations at each model vertical level and latitudes above $60^{\circ} \mathrm{N}$ are averaged over $90^{\circ}$ longitudes segments of the Arctic, indicated on the map on the left upper corner of each plot.

colder surface temperature in the equatorial Pacific. The opposite signs of perturbations in the equatorial Pacific and in Scandinavia maintain a planetary wave trapped in the troposphere and, compared to the $\mathrm{IC}_{\mathrm{NAO}}$ pattern, a lower transport to the stratosphere (Dobricic et al., 2016).

\subsection{Total trends of BC maximum likelihood estimates}

Figure 7 shows the reconstructed total trends of $\mathrm{BC}$ wet deposition and load, as the sum of the winter seasonal mean of maximum likelihood estimates associated with three independent atmospheric patterns ( $\mathrm{IC}_{\mathrm{NAO}}, \mathrm{IC}_{\mathrm{SB}}$ and $\mathrm{IC}_{\mathrm{ENSO}}$ ) multiplied by their temporal trends. The $\mathrm{BC}$ wet deposition in winter increased in the last decades due to changing atmospheric circulation over a large part of the polar region. The largest increases were estimated over the Barents Sea, the Kara Sea and the Fram Strait, southern Greenland, Alaska and the Canadian Archipelago, but the increasing deposition trend extends over most of the Arctic Ocean covered by sea ice in winter (the grey line in Fig. 7 represents the limit of sea-ice- and snow-covered areas averaged since the 1980s). Decreasing BC wet deposition is estimated over most of Siberia and the Laptev Sea and East Siberian Sea. The trend of atmospheric load of $\mathrm{BC}$ reconstructed by the three ICs shows a net increasing trend over the Arctic north of about $75^{\circ} \mathrm{N}$ and the decreasing trend over the mid-latitudes, except over western Russia, the Scandinavian Peninsula and the Norwegian Sea. The trends reconstructed by the MLE analysis are similar to the trends simulated by the FIX2000 

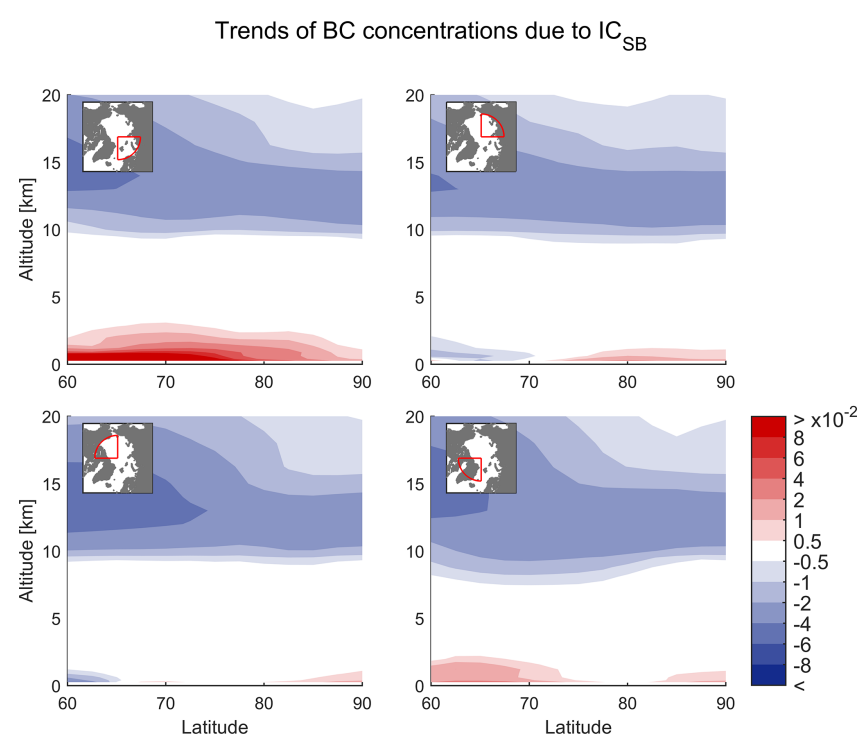

Figure 6. Winter (DJF) trends (1980-2005) of maximum likelihood estimates of $\mathrm{BC}$ concentrations $\left(\mathrm{ng} \mathrm{kg}^{-1} \mathrm{yr}^{-1}\right.$ ) associated with $\mathrm{IC}_{\mathrm{SB}}$ circulation pattern. $\mathrm{BC}$ concentrations at each model vertical level and latitudes above $60^{\circ} \mathrm{N}$ are averaged over $90^{\circ}$ longitudes segments of the Arctic, indicated on the map on the left upper corner of each plot.

chemistry-climate model simulation (Fig. 3a, d). In particular wet deposition trends are well represented in terms of both magnitude and spatial distribution. The trend of $\mathrm{BC}$ load in the FIX2000 simulation is not significant over the polar region; however, part of the noise was removed from the coupled atmospheric chemistry anomalies by performing and EOF transformation and retaining only the components with largest eigenvalues.

The temporal variability of the $\mathrm{BC}$ deposition anomalies in the period of 1980-2015 may be estimated for any area and for each pattern. In particular it is interesting to evaluate the combined and individual impacts of $\mathrm{IC}_{\mathrm{NAO}}, \mathrm{IC}_{\mathrm{SB}}$ and $\mathrm{IC}_{\mathrm{ENSO}}$ patterns on the total $\mathrm{BC}$ wet deposition and load over the Arctic Ocean, between 80 and $90^{\circ}$ N. Figure 8 shows that the $\mathrm{IC}_{\mathrm{NAO}}$ pattern produces deposition anomalies with a smaller interannual variability than those driven by the $\mathrm{IC}_{\mathrm{SB}}$ pattern. The contribution of $\mathrm{IC}_{\mathrm{ENSO}}$ to the total deposition is relevant only in the third quadrant of the Arctic $\left(180-90^{\circ} \mathrm{W}\right)$, north of the Canadian Archipelago. The largest variability is found in the first quadrant, north of Barents and Kara seas, up to a factor of 10 larger than the other sectors of the Arctic. Deposition anomalies from the $\mathrm{IC}_{\mathrm{NAO}}$ pattern are mostly negative until the year 2000 and after become positive. Those from the $\mathrm{IC}_{\mathrm{SB}}$ pattern show a strong increase after the year 2000, which dominates the whole trend from 1980 to 2015, corresponding well to an acceleration in the winter sea-ice decrease rate over the Barents Sea that is often coupled with the formation of the anticyclonic anomaly over Scandinavia (Cohen et al., 2014; Dobricic et al., 2016; Sato et al., 2014; (a) Wet deposition [kg yr-1]
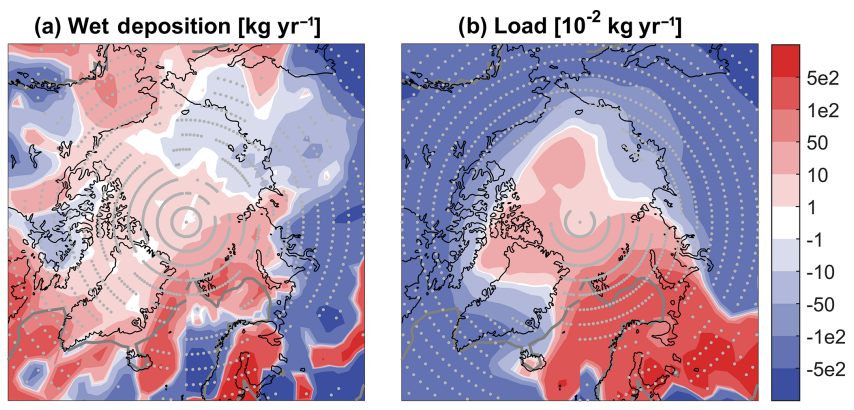

Figure 7. Total winter (DJF) trends (1980-2015) of maximum likelihood estimates (MLEs) of BC wet deposition $\left(\mathrm{kg} \mathrm{yr}^{-1}\right)$ and load $\left(\mathrm{kg} \times 10^{-2} \mathrm{yr}^{-1}\right)$ associated with three atmospheric circulation patterns $\left(\right.$ Total $\left.=\mathrm{IC}_{\mathrm{NAO}}+\mathrm{IC}_{\mathrm{SB}}+\mathrm{IC}_{\mathrm{ENSO}}\right)$. The grey line represents the mean winter sea ice and snow cover larger than $50 \%$ from 1980 to now. Grey dots represent the grid points with trend significant at $5 \%$ level.

Screen et al., 2013). Figure 9 shows the temporal contribution of $\mathrm{IC}_{\mathrm{NAO}}, \mathrm{IC}_{\mathrm{SB}}$ and $\mathrm{IC}_{\mathrm{ENSO}}$ patterns to the total $\mathrm{BC}$ load over the Arctic quadrants. In this case, the $\mathrm{IC}_{\mathrm{NAO}}$ pattern drives the interannual variability, with negative values until the late 1990s and positive in the last 15 years. The $\mathrm{IC}_{\mathrm{NAO}}$ pattern affects BC load over the entire Arctic in a similar way, while the contribution of the $\mathrm{IC}_{\mathrm{SB}}$ pattern has an opposite trend except for the first quadrant, where it is only a small fraction of the total variability. As discussed in the previous section, the $\mathrm{IC}_{\mathrm{SB}}$ pattern increase the transport of $\mathrm{BC}$ directly from central Europe to the Barents and Kara Sea, while it decreases the transport from Siberia. The $\mathrm{IC}_{\mathrm{SB}}$ pattern has a negative contribution in the last 10 years in the other parts of the Arctic, and in this regions it can be as large as the $\mathrm{IC}_{\mathrm{NAO}}$ contribution. In Figs. 8 and 9 we can see that also the temporal variability is partially reconstructed by the applied Bayesian statistical approach. The correlation coefficients between the interannual variability reconstructed by the MLE and the FIX2000 model simulation for the common period 1980-2005 range between 0.35 and 0.4 for BC wet deposition and between 0.14 and 0.41 for $\mathrm{BC}$ load over the different sectors of the Arctic.

\subsection{Uncertainty of the BC maximum likelihood estimates}

In order to test the robustness of the statistical method, we have estimated the MLE of pollutant distributions for a set of eight combinations of coupled atmospheric reanalysis and BC simulations (Table 1). Dobricic et al. (2016) applied the ICA to two different atmospheric reanalysis of the period 1980-2015, NCEP and ERA-Interim, and similar atmospheric patterns and trends of the ICs were found. A first set of MLEs combined the atmospheric patterns computed from NCEP and ERA-Interim with two global chemistry-climate simulations, which used constant anthropogenic emissions 
Table 1. Combination of atmospheric reanalysis, global chemistryclimate model simulations and time periods used to generate MLE of BC deposition and load.

\begin{tabular}{llll}
\hline Estimate name & $\begin{array}{l}\text { Atmospheric } \\
\text { reanalysis }\end{array}$ & BC simulation & Period \\
\hline NCEP-2000-A & NCEP & FIX2000 & $1980-2005$ \\
ERA-2000-A & ERA-Interim & FIX2000 & $1980-2005$ \\
NCEP-1980-A & NCEP & FIX1980 & $1980-2005$ \\
ERA-1980-A & ERA-Interim & FIX1980 & $1980-2005$ \\
NCEP-REF-B & NCEP & REF & $1993-2005$ \\
ERA-REF-B & ERA-Interim & REF & $1993-2005$ \\
NCEP-2000-B & NCEP & FIX2000 & $1993-2005$ \\
ERA-2000-B & ERA-Interim & FIX2000 & $1993-2005$ \\
\hline
\end{tabular}

(FIX2000 and FIX1980; see Sect. 2.3). The MLEs were computed using the simulated pollutant fields for the longest period available: 26 years from 1980 to 2005. The results from NCEP-2000-A have been explained in details in the previous sections.

Figure 10 shows the total trends $\left(\mathrm{IC}_{\mathrm{NAO}}+\mathrm{IC}_{\mathrm{SB}}+\mathrm{IC}_{\mathrm{ENSO}}\right)$ of $\mathrm{BC}$ wet deposition estimated using the FIX2000 and FIX1980 simulations to build the pollutants and atmospheric coupled anomalies. All four estimates are consistent in terms of geographical distribution, magnitude of the estimated trends and their statistical significance. Consistent results are obtained also for the total trends of BC load (Fig. S3). Only small differences are due to the two atmospheric reanalysis and the two atmospheric composition simulations, which have a different geographical distribution of anthropogenic emissions (Fig. S1).

In a second set of MLEs, we used the REF model simulation, which includes annually varying anthropogenic emissions. In this case, the sudden drop of anthropogenic emissions in Eastern Europe and Russia and the increase in East Asia in the early 1990s (Fig. S1d) introduced a strong discontinuous change in the transport variability that was impossible to resolve by the statistical method. Thus we chose a shorter period to form the simulated chemistry and atmospheric coupled anomalies, 13 years (1993-2005) after the drop of anthropogenic emissions. Figure 11 shows the estimated trends of BC wet deposition (trends of BC load are shown in Fig. S4) using only 13 years of coupled anomalies, from the REF simulation and also from the FIX2000 simulation for comparison. Also in this case the results shown in Figs. 10 and 11 are consistent, using a shorter period to form the simulated coupled anomalies and with both constant and varying anthropogenic emissions (without large emission changes in a short time). In the most remote Arctic region covered by sea ice, far from the main anthropogenic sources, the entire set of estimated trends of $\mathrm{BC}$ transport and deposition are very close to each other, meaning that the applied methodology can robustly approximate the transport
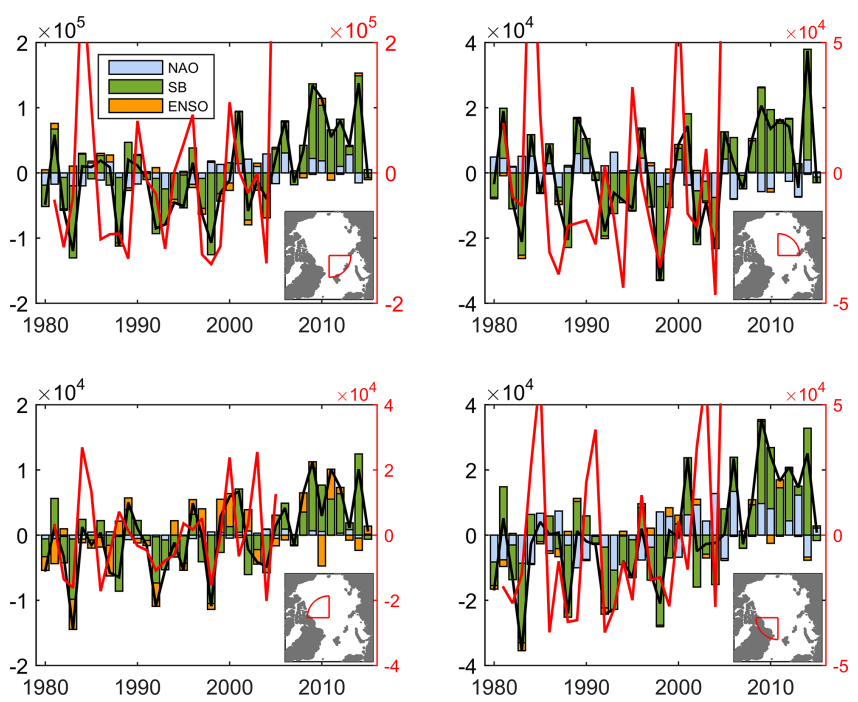

Figure 8. Temporal variability of total $\mathrm{BC}$ wet deposition anomaly over $90^{\circ}$ longitude segments of the Arctic and between 80 and $90^{\circ} \mathrm{N}\left(\mathrm{kg} \mathrm{yr}^{-1}\right)$ related to the circulation patterns $\mathrm{IC}_{\mathrm{NAO}}, \mathrm{IC}_{\mathrm{SB}}$ and $\mathrm{IC}_{\mathrm{ENSO}}$. The black line is the sum of the three components; the red line (right $y$ axis) is the total BC wet deposition anomaly from the FIX2000 simulation.
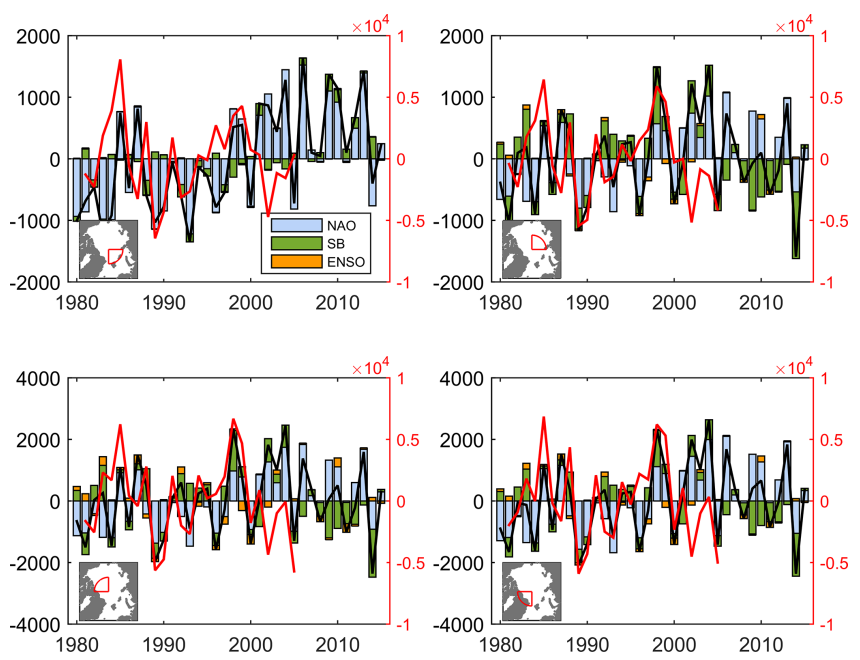

Figure 9. Temporal variability of total BC load anomaly over $90^{\circ}$ longitude segments of the Arctic and between 80 and $90^{\circ} \mathrm{N}$ $\left(\mathrm{kg} \mathrm{yr}^{-1}\right)$ related to the circulation patterns $\mathrm{IC}_{\mathrm{NAO}}, \mathrm{IC}_{\mathrm{SB}}$ and $\mathrm{IC}_{\mathrm{ENSO}}$. The black line is the sum of the three components; the red line (right $y$ axis) is the total BC load anomaly from the FIX2000 simulation.

of pollutants to this region and the trends associated with different large-scale circulation patterns.

\section{Conclusions}

The feedbacks between the global warming and Arctic amplification with sea-ice retreat and impacts on large-scale at- 


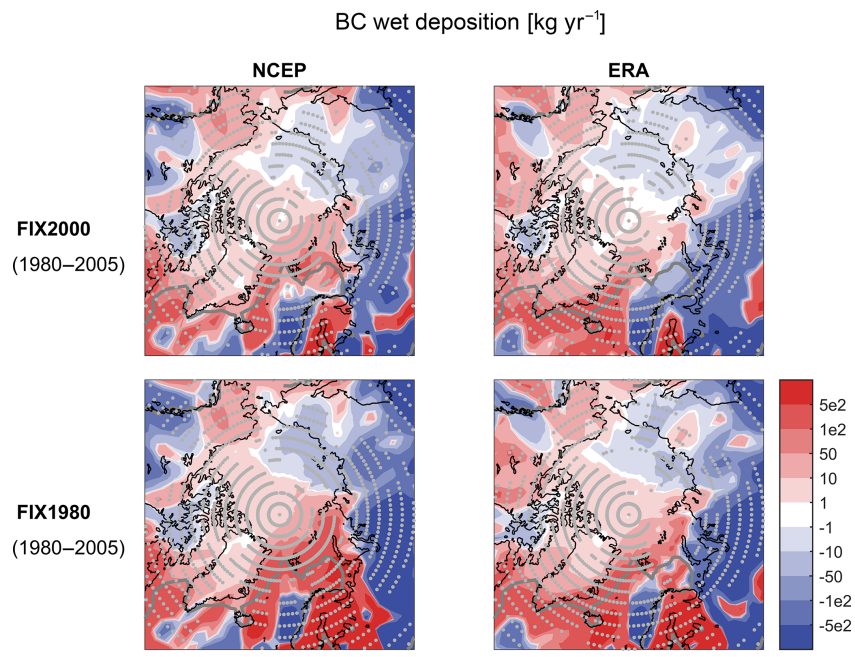

Figure 10. Four different estimates (see also Table 1) of total trends of maximum likelihood BC wet deposition $\left(\mathrm{kg} \mathrm{yr}^{-1}\right)$ associated with three atmospheric circulation patterns (To$\mathrm{tal}=\mathrm{NAO}+\mathrm{SB}+\mathrm{ENSO})$. The grey line represents the mean winter sea ice and snow cover larger than $50 \%$ from 1980 to now. Grey dots represent the grid points with trend significant at $5 \%$ level.

mospheric circulation are still contradictory. The response of mid-latitude weather to the Arctic warming and sea-ice cover changes of the last decades is highly uncertain due to nonlinear processes involved in the Arctic and sub-Arctic climate system (Overland et al., 2016). Some studies find only weak or non-existent relationships between mid-latitude weather structures and Arctic warming (e.g. Screen and Simmonds, 2013; Barnes et al., 2014), while others found correlations between sea-ice retreat in winter over the Barents and Kara seas and hemispheric-scale impacts (e.g. Deser et al., 2007; Petoukhov and Semenov, 2010; Screen et al., 2013; Mori et al., 2014; Di Capua and Coumou, 2016). Recently, the trends from two atmospheric reanalysis (Figs. 2 and S3 of Dobricic et al., 2016) of winter near-surface warming of the Northern Hemisphere are approximated by three independent components which are also very similar to well-known atmospheric oscillations, the NAO, SB and ENSO. We developed a statistical algorithm to combine the estimates of these independent components $\left(\mathrm{IC}_{\mathrm{NAO}}, \mathrm{IC}_{\mathrm{SB}}\right.$ and $\left.\mathrm{IC}_{\mathrm{ENSO}}\right)$ with chemistry-climate model simulations of transport and deposition of $\mathrm{BC}$ over the Arctic. In this way we estimate how changes in the large-scale atmospheric circulation impact the $\mathrm{BC}$ transport and deposition independently of the changes in emissions. For a given independent component of the atmospheric variability our algorithm estimates the most likelihood deposition and load of BC consistent with the variability of the atmosphere-chemistry coupled anomalies. To test the robustness of the method and the spread of the possible solutions, the method is applied with two atmospheric reanalysis, NCEP and ERA-Interim, and three realizations of coupled anomalies from ECHAM5-HAMMOZ

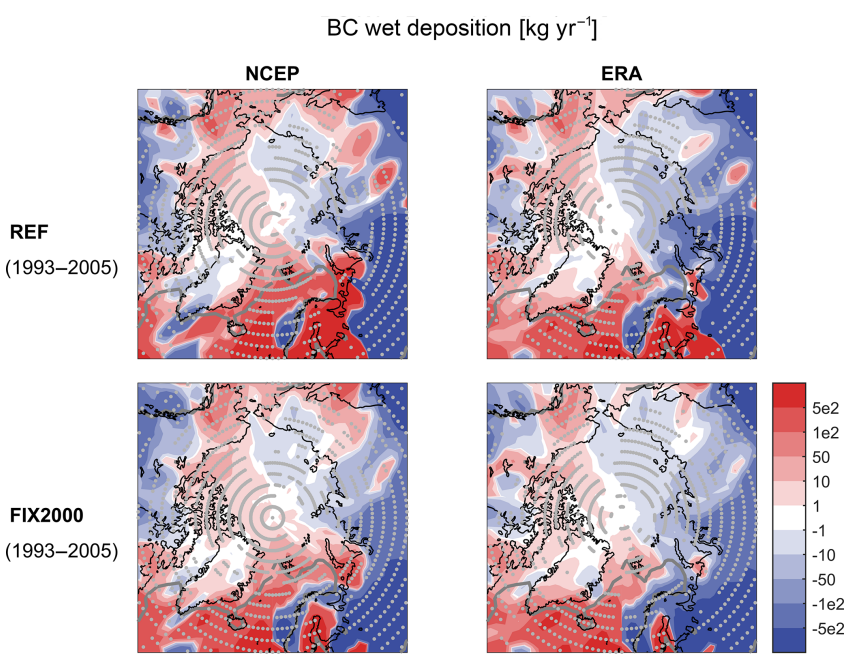

Figure 11. Four different estimates (see also Table 1) of total trends of maximum likelihood BC wet deposition $\left(\mathrm{kg} \mathrm{yr}^{-1}\right)$ associated with three atmospheric circulation patterns (To$\mathrm{tal}=\mathrm{NAO}+\mathrm{SB}+\mathrm{ENSO}$ ). The grey line represents the mean winter sea ice and snow cover larger than $50 \%$ from 1980 to now. Grey dots represent the grid points with trend significant at $5 \%$ level.

global model simulations, with constant and annually varying anthropogenic emissions.

The main results are summarized in the following points.

- The trends of BC concentrations and deposition fluxes simulated by a global chemistry-climate model (ECHAM5-HAMMOZ) indicated a strong reduction of near-surface transport and deposition to the Arctic due to anthropogenic emission reductions in Eurasia, in agreement with observations and other modelling studies (Gong et al., 2010; Hirdman et al., 2010), and an increasing BC load mainly due to the emissions from East Asia (Sharma et al., 2013). In contrast, model simulations with constant anthropogenic emissions indicated how the effect of changing meteorology in the last decades may have also determined significant trends of $\mathrm{BC}$ transport to the Arctic.

- The increasing trend of the anticyclonic circulation anomaly over the Arctic $\left(\mathrm{IC}_{\mathrm{NAO}}\right)$ determines a decrease of the pollution transport pathway from Eurasia to the Arctic, with a decrease in $\mathrm{BC}$ surface concentrations and deposition particularly in the eastern Arctic. However, the $\mathrm{IC}_{\mathrm{NAO}}$ trend favours a stable vertical stratification which determines an increase of $\mathrm{BC}$ transport in the upper troposphere from East Asia and North America with increasing trend of total column $\mathrm{BC}$ concentrations over the entire Arctic Ocean.

- A second component, named $\mathrm{IC}_{\mathrm{SB}}$, directly transports $\mathrm{BC}$ in the Arctic lower troposphere from central Europe. The increasing trend of an anticyclonic anomaly over 
Scandinavia and Western Siberia favours the transport of air pollution directly from Europe to the Barents Sea with a significant increase of $\mathrm{BC}$ wet deposition over the entire Arctic Ocean. Also, this pattern determines a decrease of pollution transport from East Eurasia to the Arctic and an overall decrease of BC load over the entire Arctic upper troposphere, except over the Barents Sea where the surface concentration trends is strongly increasing.

- A third component, which is more related to anomalies in the tropical Pacific Ocean and named $\mathrm{IC}_{\mathrm{ENSO}}$, has a smaller and statistically less significant impact on the transport and deposition of $\mathrm{BC}$ to the Arctic.

- The combined impact of all three atmospheric patterns on $\mathrm{BC}$ wet deposition determines a significant increasing trend between 1980 and 2015 over almost the entire Arctic Ocean, the Barents Sea and Fram Strait, Greenland, Alaska and the Canadian Archipelago. A small, significant decreasing trend is estimated in the East Siberian and Laptev seas. The BC load increases over the whole Arctic Ocean, with a significant trend only north of Greenland and the Barents Sea.

- The estimated interannual variability and trend of BC wet deposition over the Arctic Ocean is mainly driven by the $\mathrm{IC}_{\mathrm{SB}}$ pattern, with positive anomalies persisting for the last 10 years, 2005-2015. Smaller contributions are estimated for $\mathrm{IC}_{\mathrm{ENSO}}$ between 180 and $90^{\circ} \mathrm{W}$ and for NAO between 90 and $0^{\circ} \mathrm{W}$. The interannual variability and trend of BC load over the Arctic is mainly driven by the $\mathrm{IC}_{\mathrm{NAO}}$ atmospheric pattern, in particular north of the Barents Sea. In the other sectors of the Arctic, $\mathrm{IC}_{\mathrm{SB}}$ also contributes to the load total variability.

- We have shown the robustness of a Bayesian approach to estimate the maximum likelihood distribution and trends of air pollutants associate with specific atmospheric patterns. The estimates obtained from different atmospheric reanalysis and global chemistry-climate model simulations are consistent. Problems may arise to resolve the total variability in presence of strong emission discontinuous changes. Although it was possible to separate the effects of changing anthropogenic emissions from the meteorological variability using only global chemistry-climate simulations, MLE further provided information on the feedback impacts of single atmospheric processes related to global warming and sea ice retreat on pollution transport. By using outputs from existing coupled model simulations the method may be applied with other atmospheric processes related to the pollution transport and to other temporal intervals.

Our results show how winter atmospheric processes linked to enhanced Arctic warming and sea-ice retreat may impact the $\mathrm{BC}$ deposition on the sea ice itself. $\mathrm{BC}$ deposition is mainly decreasing over the area that in the recent years is characterized by the thin first-year sea ice, while it is increasing over the area with the thicker multi-year sea ice, which has become a smaller fraction of the total sea-ice cover in the summers of recent years. During the winter polar night the deposited BC has no impact on sea-ice melting. When the sun appears in the spring the shortwave radiation starts to melt the fresh snow deposited on the sea ice. The BC impact on the albedo may be the most important at the end of the winter season, just before the snow starts to melt and surface becomes darker. Therefore, the BC deposition in winter may accelerate the initial melting of the snow and by an integrated effect it may result in the increased melting at the end of summer. The first-year sea ice may be completely melted every summer and the decrease of the $\mathrm{BC}$ deposition might not be the most important factor controlling its coverage in the late summer. However, with the increased deposition of $\mathrm{BC}$ the multi-year sea ice may melt more and its thickness may become reduced with respect to the previous year. If this process happens consistently over several decades it might significantly contribute to reduction of the thickness of the multi-year sea ice. Our estimate of the temporal variability of the BC deposition over the multi-year sea ice indicates that the deposition in the winter due to the sea-ice retreat feedback increased especially in the last 10 years.

The increasing trend of the $\mathrm{BC}$ deposition due to changes in atmospheric circulation emphasizes the importance of the reduction of $\mathrm{BC}$ anthropogenic emissions in the midlatitudes. In particular the $\mathrm{IC}_{\mathrm{SB}}$ pattern favours the transport to the Arctic Ocean of polluted air masses from Europe and increased deposition on the multi-year sea ice. Policies that reduced anthropogenic emissions in the last decades, therefore, reduced the risk of a further acceleration of the melting of the multi-year sea ice. A strong shift of the anthropogenic emissions from North America and Europe to East and South Asia also contributed to reduce the transport of $\mathrm{BC}$ to the Arctic from Eurasia, which represents the main transport pathway. We may have an indication of the impact of this geographical emissions shift by comparing the trends estimated using the FIX2000 and FIX1980 BC simulations (Fig. S5). The BC deposition trend increased over the East Siberian and Laptev Sea considering the anthropogenic emissions of year 2000 compared to 1980, indicating that the contribution from the Asian emissions may play an important role in the future (e.g. Sand et al., 2015). This increase is affecting deeper into the Arctic Ocean in particular in association with the $\mathrm{IC}_{\mathrm{NAO}}$ pattern. A similar impact of the increasing emissions in Asia was estimated for the BC burden, in particular associated with $\mathrm{IC}_{\mathrm{NAO}}$ and extending from Siberia, across the Arctic Ocean up to the Canadian Archipelago and Greenland.

In order to further understand the link between global warming and trends of BC transport and deposition, it will be necessary to extend the study to other seasons. In partic- 
ular the major precipitation and wet deposition of BC happening in the summer when the reduction of the ice cover in the recent years is the largest. Furthermore, although the use of different estimates for atmospheric patterns and coupled atmosphere-chemistry relationships provides some information on their uncertainty, in the future the same method may be applied with several coupled models and multi-year observations in the Arctic to further assess the uncertainties. The same methodology may be also applied to estimate trends of $\mathrm{BC}$ transport to the Arctic associated with atmospheric circulation changes in the future, for example using the global climate simulations instead of atmospheric reanalysis.

Data availability. The ERA-Interim atmospheric reanalysis data are available at https://www.ecmwf.int/en/research/ climate-reanalysis/era-interim. The NCEP atmospheric reanalysis data are available at https://www.esrl.noaa.gov/psd/data/ reanalysis/reanalysis.shtml. All ECHAM5-HAMMOZ model results are archived on the server of the Air and Climate Unit, Directorate of Energy, Transport and Climate, Joint Research Centre, and available upon request. Please contact Luca Pozzoli (luca.pozzoli@ec.europa.eu) for access.

\section{The Supplement related to this article is available online at https://doi.org/10.5194/acp-17-11803-2017- supplement.}

Competing interests. The authors declare that they have no conflict of interest.

Acknowledgements. We thank the anonymous reviewers for the helpful comments and suggestions during the review phase.

Edited by: Timothy J. Dunkerton

Reviewed by: three anonymous referees

\section{References}

AMAP: AMAP Assessment 2015: Black carbon and ozone as Arctic climate forcers, available from: http://www.amap.no/ documents/download/2506 (last access: 25 September 2017), 2015.

Aoki, T., Aoki, T., Fukabori, M., Hachikubo, A., Tachibana, Y., and Nishio, F.: Effects of snow physical parameters on spectral albedo and bidirectional reflectance of snow surface, J. Geophys. Res., 105, 10219, https://doi.org/10.1029/1999JD901122, 2000.

Appenzeller, C., Schwander, J., Sommer, S., and Stocker, T. F.: The North Atlantic Oscillation and its imprint on precipitation and ice accumulation in Greenland, Geophys. Res. Lett., 25, 1939-1942, 1998.

Auvray, M., Bey, I., Llull, E., Schultz, M. G., and Rast, S.: A model investigation of tropospheric ozone chemical tendencies in long- range transported pollution plumes, J. Geophys. Res.-Atmos., 112, 1-17, https://doi.org/10.1029/2006JD007137, 2007.

Barnes, E. A., Dunn-sigouin, E., Masato, G., and Woollings, T.: Exploring recent trends in Northern Hemisphere blocking, Geophys. Res. Lett., 2, 638-644, https://doi.org/10.1002/2013GL058745, 2014.

Barrie, L. A.: Arctic air pollution: An overview of current knowledge, Atmos. Environ., 20, 643-663, https://doi.org/10.1016/0004-6981(86)90180-0, 1986.

Bourgeois, Q. and Bey, I.: Pollution transport efficiency toward the Arctic: Sensitivity to aerosol scavenging and source regions, 116, J. Geophys. Res.-Atmos., 1-18, https://doi.org/10.1029/2010JD015096, 2011.

Byrd, R., Lu, P., Nocedal, J., and Zhu, C.: A Limited Memory Algorithm for Bound Constrained Optimization, SIAM J. Sci. Comput., 16, 1190-1208, https://doi.org/10.1137/0916069, 1995.

Di Capua, G. and Coumou, D.: Changes in meandering of the Northern Hemisphere circulation, Environ. Res. Lett., 11, 094028, https://doi.org/10.1088/1748-9326/11/9/094028, 2016.

Cohen, J., Screen, J. A., Furtado, J. C., Barlow, M., Whittleston, D., Coumou, D., Francis, J., Dethloff, K., Entekhabi, D., Overland, J., and Jones, J.: Recent Arctic amplification and extreme mid-latitude weather, Nat. Geosci., 7, 627-637, https://doi.org/10.1038/ngeo2234, 2014.

Comiso, J. C.: Large decadal decline of the arctic multiyear ice cover, J. Climate, 25, 1176-1193, https://doi.org/10.1175/JCLID-11-00113.1, 2012.

Conway, H., Gades, A., Raymond, C. F.: Albedo of dirty snow during conditions of melt, Water Resour. Res., 32, 1713-1718, https://doi.org/10.1029/96WR00712, 1996.

Dee, D. P., Uppala, S. M., Simmons, A. J., Berrisford, P., Poli, P., Kobayashi, S., Andrae, U., Balmaseda, M. A., Balsamo, G., Bauer, P., Bechtold, P., Beljaars, A. C. M., van de Berg, L., Bidlot, J., Bormann, N., Delsol, C., Dragani, R., Fuentes, M., Geer, A. J., Haimberger, L., Healy, S. B., Hersbach, H., Holm, E. V., Isaksen, L., Kallberg, P., Kohler, M., Matricardi, M., Mcnally, A. P., Monge-Sanz, B. M., Morcrette, J. J., Park, B. K., Peubey, C., de Rosnay, P., Tavolato, C., Thepaut, J. N., and Vitart, F.: The ERA-Interim reanalysis: Configuration and performance of the data assimilation system, Q. J. Roy. Meteor. Soc., 137, 553-597, https://doi.org/10.1002/qj.828, 2011.

Deser, C., Tomas, R. A., and Peng, S.: The transient atmospheric circulation response to North Atlantic SST and sea ice anomalies, J. Climate, 20, 4751-4767, https://doi.org/10.1175/JCLI4278.1, 2007.

Diehl, T., Heil, A., Chin, M., Pan, X., Streets, D., Schultz, M., and Kinne, S.: Anthropogenic, biomass burning, and volcanic emissions of black carbon, organic carbon, and $\mathrm{SO}_{2}$ from 1980 to 2010 for hindcast model experiments, Atmos. Chem. Phys. Discuss., https://doi.org/10.5194/acpd-12-24895-2012, 2012.

Dobricic, S., Vignati, E., and Russo, S.: Large-scale atmospheric warming in winter and the Arctic sea ice retreat, J. Climate, 29 , 2869-2888, https://doi.org/10.1175/JCLI-D-15-0417.1, 2016.

Döscher, R., Vihma, T., and Maksimovich, E.: Recent advances in understanding the Arctic climate system state and change from a sea ice perspective: a review, Atmos. Chem. Phys., 14, 1357113600, https://doi.org/10.5194/acp-14-13571-2014, 2014.

Eckhardt, S., Quennehen, B., Olivié, D. J. L., Berntsen, T. K., Cherian, R., Christensen, J. H., Collins, W., Crepinsek, S., 
Daskalakis, N., Flanner, M., Herber, A., Heyes, C., Hodnebrog, Ø., Huang, L., Kanakidou, M., Klimont, Z., Langner, J., Law, K. S., Lund, M. T., Mahmood, R., Massling, A., Myriokefalitakis, S., Nielsen, I. E., Nøjgaard, J. K., Quaas, J., Quinn, P. K., Raut, J.-C., Rumbold, S. T., Schulz, M., Sharma, S., Skeie, R. B., Skov, H., Uttal, T., von Salzen, K., and Stohl, A.: Current model capabilities for simulating black carbon and sulfate concentrations in the Arctic atmosphere: a multi-model evaluation using a comprehensive measurement data set, Atmos. Chem. Phys., 15, 9413-9433, https://doi.org/10.5194/acp-15-9413-2015, 2015.

Eleftheriadis, K., Vratolis, S., and Nyeki, S.: Aerosol black carbon in the European Arctic?: Measurements at Ny-Ålesund, Svalbard from 1998-2007, Geophys. Res. Lett., 36, L02809, https://doi.org/10.1029/2008GL035741, 2009.

Endresen, Ø., Sørgard, E., Sundet, J., Dalsøren, S., Isaksen, I., and Berglen, T.: Emission from international sea transportation and environmental impact, J. Geophys. Res., 108, 14.1-14.22, https://doi.org/10.1029/2002JD002898, 2003.

Feldstein, S. B. and Lee, S.: Intraseasonal and interdecadal jet shifts in the Northern Hemisphere: The role of warm pool tropical convection and sea ice, J. Climate, 27, 6497-6518, https://doi.org/10.1175/JCLI-D-14-00057.1, 2014.

Flanner, M. G.: Arctic climate sensitivity to local black carbon, J. Geophys. Res.-Atmos., 118, 1840-1851, https://doi.org/10.1002/jgrd.50176, 2013.

Flanner, M. G. and Zender, C. S.: Linking snowpack microphysics and albedo evolution, J. Geophys. Res.-Atmos., 111, 1-12, https://doi.org/10.1029/2005JD006834, 2006.

Ganzeveld, L. and Lelieveld, J.: Dry deposition parameterization in a chemistry general circulation model and its influence on the distribution of reactive trace gases, J. Geophys. Res.-Atmos., 100, 20999-21012, https://doi.org/10.1029/95JD02266, 1995.

Gong, S. L., Zhao, T. L., Sharma, S., Sauntry, D. T., Lavoué, D., Zhang, X. B., Leaitch, W. R., and Barrie, L. A.: Identification of trends and interannual variability of sulfate and black carbon in the Canadian High Arctic?: 1981-2007, J. Geophys. Res.Atmos., 115, 1-9, https://doi.org/10.1029/2009JD012943, 2010.

Hadley, O. L. and Kirchstetter, T. W.: Black-carbon reduction of snow albedo, Nat. Clim. Chang., 2, 437-440, https://doi.org/10.1038/nclimate1433, 2012.

Hannachi, A., Unkel, S., Trendafilov, N. T., and Jolliffe, I. T.: Independent component analysis of climate data: A new look at EOF rotation, J. Climate, 22, 2797-2812, https://doi.org/10.1175/2008JCLI2571.1, 2009.

Henning, S., Bojinski, S., Diehl, K., Ghan, S., Nyeki, S., Weingartner, E., Wurzler, S., and Baltensperger, U.: Aerosol partitioning in natural mixed-phase clouds, Geophys. Res. Lett., 31, L06101, https://doi.org/10.1029/2003GL019025, 2004.

Hirdman, D., Burkhart, J. F., Sodemann, H., Eckhardt, S., Jefferson, A., Quinn, P. K., Sharma, S., Ström, J., and Stohl, A.: Long-term trends of black carbon and sulphate aerosol in the Arctic: changes in atmospheric transport and source region emissions, Atmos. Chem. Phys., 10, 9351-9368, https://doi.org/10.5194/acp-109351-2010, 2010.

Hyvärinen, A. and Oja, E.: Independent component analysis: Algorithms and applications, Neural Networks, 13, 411-430, https://doi.org/10.1016/S0893-6080(00)00026-5, 2000.

Jacob, D. J., Crawford, J. H., Maring, H., Clarke, A. D., Dibb, J. E., Emmons, L. K., Ferrare, R. A., Hostetler, C. A., Russell, P.
B., Singh, H. B., Thompson, A. M., Shaw, G. E., McCauley, E., Pederson, J. R., and Fisher, J. A.: The Arctic Research of the Composition of the Troposphere from Aircraft and Satellites (ARCTAS) mission: design, execution, and first results, Atmos. Chem. Phys., 10, 5191-5212, https://doi.org/10.5194/acp10-5191-2010, 2010.

Jiao, C., Flanner, M. G., Balkanski, Y., Bauer, S. E., Bellouin, N., Berntsen, T. K., Bian, H., Carslaw, K. S., Chin, M., De Luca, N., Diehl, T., Ghan, S. J., Iversen, T., Kirkevåg, A., Koch, D., Liu, X., Mann, G. W., Penner, J. E., Pitari, G., Schulz, M., Seland, Ø., Skeie, R. B., Steenrod, S. D., Stier, P., Takemura, T., Tsigaridis, K., van Noije, T., Yun, Y., and Zhang, K.: An AeroCom assessment of black carbon in Arctic snow and sea ice, Atmos. Chem. Phys., 14, 2399-2417, https://doi.org/10.5194/acp14-2399-2014, 2014.

Kalnay, E., Kanamitsu, M., Kistler, R., Collins, W., Deaven, D., Gandin, L., Iredell, M., Saha, S., White, G., Woollen, J., Zhu, Y., Chelliah, M., Ebisuzaki, W., Higgins, W., Janowiak, J., Mo, K. C., Ropelewski, C., Wang, J., Leetmaa, A., Reynolds, R., Jenne, R., and Joseph, D.: The NCEP/NCAR 40-year reanalysis project, B. Am. Meteorol. Soc., 77, 437-471, https://doi.org/10.1175/15200477(1996)077<0437:TNYRP>2.0.CO;2, 1996.

Kim, D., Chin, M., Yu, H., Diehl, T., Tan, Q., Kahn, R. A., Tsigaridis, K., Bauer, S. E., Takemura, T., Pozzoli, L., Bellouin, N., Schulz, M., Peyridieu, S., Chédin, A., and Koffi, B.: Sources, sinks, and transatlantic transport of North African dust aerosol: A multimodel analysis and comparison with remote sensing data, J. Geophys. Res.-Atmos., 119, 6259-6277, https://doi.org/10.1002/2013JD021099, 2014.

Klonecki, A.: Seasonal changes in the transport of pollutants into the Arctic troposphere-model study, J. Geophys. Res., 108, 8367, https://doi.org/10.1029/2002JD002199, 2003.

Kwok, R.: Outflow of Arctic Ocean Sea Ice into the Greenland and Barents Seas: 1979-2007, J. Climate, 22, 2438-2457, https://doi.org/10.1175/2008JCLI2819.1, 2009.

Kwok, R. and Rothrock, D. A.: Decline in Arctic sea ice thickness from submarine and ICESat records: 1958-2008, Geophys. Res. Lett., 36, 1-5, https://doi.org/10.1029/2009GL039035, 2009.

Mann, H. B.: Nonparametric Tests Against Trend, Econometrica, 13, 245-259, https://doi.org/10.2307/1907187, 1945.

Maslanik, J., Stroeve, J., Fowler, C., and Emery, W.: Distribution and trends in Arctic sea ice age through spring 2011, Geophys. Res. Lett., 38, 2-7, https://doi.org/10.1029/2011GL047735, 2011.

Mori, M., Watanabe, M., Shiogama, H., Inoue, J., and Kimoto, M.: Robust Arctic sea-ice influence on the frequent Eurasian cold winters in past decades, Nat. Geosci., 7, 869-874, https://doi.org/10.1038/ngeo2277, 2014.

Mosley-Thompson, E., Readinger, C. R., Craigmile, P., Thompson, L. G., and Calder, C. A.: Regional sensitivity of Greenland precipitation to NAO variability, Geophys. Res. Lett., 32, 3-6, https://doi.org/10.1029/2005GL024776, 2005.

Moteki, N. and Kondo, Y.: Effects of Mixing State on Black Carbon Measurements by Laser-Induced Incandescence Effects of Mixing State on Black Carbon Measurements by Laser-Induced Incandescence, Aerosol Sci. Tech., 41, 398-417, https://doi.org/10.1080/02786820701199728, 2007. 
Overland, J. E. and Wang, M.: Large-scale atmospheric circulation changes are associated with the recent loss of Arctic sea ice, Tellus A, 62, 1-9, https://doi.org/10.1111/j.16000870.2009.00421.x, 2010.

Overland, J. E., Dethloff, K., Francis, J. A., Hall, R. J., Hanna, E., Kim, S., Screen, J. A., Shepherd, T. G., and Vihma, T.: Nonlinear response of mid-latitude weather to the changing Arctic, Nat. Clim. Chang., 6, 992-999, https://doi.org/10.1038/nclimate3121, 2016.

Pan, X., Chin, M., Gautam, R., Bian, H., Kim, D., Colarco, P. R., Diehl, T. L., Takemura, T., Pozzoli, L., Tsigaridis, K., Bauer, S., and Bellouin, N.: A multi-model evaluation of aerosols over South Asia: common problems and possible causes, Atmos. Chem. Phys., 15, 5903-5928, https://doi.org/10.5194/acp15-5903-2015, 2015.

Pausata, F. S. R., Pozzoli, L., Vignati, E., and Dentener, F. J.: North Atlantic Oscillation and tropospheric ozone variability in Europe: model analysis and measurements intercomparison, Atmos. Chem. Phys., 12, 6357-6376, https://doi.org/10.5194/acp12-6357-2012, 2012.

Pausata, F. S. R., Pozzoli, L., Van Dingenen, R., Vignati, E., Cavalli, F., and Dentener, F. J.: Impacts of changes in North Atlantic atmospheric circulation on particulate matter and human health in Europe, Geophys. Res. Lett., 40, 4074-4080, 2013.

Petoukhov, V. and Semenov, V. A.: A link between reduced Barents-Kara sea ice and cold winter extremes over northern continents, J. Geophys. Res.-Atmos., 115, 1-11, https://doi.org/10.1029/2009JD013568, 2010.

Pozzoli, L., Bey, I., Rast, S., Schultz, M. G., Stier, P., and Feichter, J.: Trace gas and aerosol interactions in the fully coupled model of aerosol-chemistry-climate ECHAM5-HAMMOZ: 1. Model description and insights from the spring 2001 TRACE-P experiment, J. Geophys. Res.-Atmos., 113, D07308, https://doi.org/10.1029/2007JD009007, 2008a.

Pozzoli, L., Bey, I., Rast, S., Schultz, M. G., Stier, P., and Feichter, J.: Trace gas and aerosol interactions in the fully coupled model of aerosol-chemistry-climate ECHAM5HAMMOZ: 2. Impact of heterogeneous chemistry on the global aerosol distributions, J. Geophys. Res.-Atmos., 113, 1-15, https://doi.org/10.1029/2007JD009008, 2008b.

Pozzoli, L., Janssens-Maenhout, G., Diehl, T., Bey, I., Schultz, M. G., Feichter, J., Vignati, E., and Dentener, F.: Reanalysis of tropospheric sulfate aerosol and ozone for the period 1980-2005 using the aerosol-chemistry-climate model ECHAM5-HAMMOZ, Atmos. Chem. Phys., 11, 9563-9594, https://doi.org/10.5194/acp-11-9563-2011, 2011.

Qi, L., Li, Q., Li, Y., and He, C.: Factors controlling black carbon distribution in the Arctic, Atmos. Chem. Phys., 17, 1037-1059, https://doi.org/10.5194/acp-17-1037-2017, 2017.

Rast, S., Schultz, M., Bey, I., van Noije, T., Aghedo, A., Brasseur, G., Diehl, T., Esch, M., Ganzeveld, L., Kirchner, I., Kornblueh, L., Rhodin, A., Roeckner, E., Schmidt, H., Schröder, S., Schulzweida, U., Stier, P., Thomas, K., and Walters, S.: Evaluation of the tropospheric chemistry general circulation model ECHAM5-MOZ and its application to the analysis of the chemical composition of the troposphere with an emphasis on the late RETRO period 1990-2000, Max-Planck-Institut für Meteorologie Berichte zur Erdsystemforschung, Hamburg, 114, https://doi.org/10.17617/2.2058065, 2014.
Roeckner, E., Bäuml, G., Bonaventura, L., Brokopf, R., Esch, M., Giorgetta, M., Hagemann, S., Kirchner, I., Kornblueh, L., Manzini, E., Rhodin, A., Schlese, U., Schulzweida, U., and Tompkins, A.: The atmospheric general circulation model ECHAM 5. PART I: Model description https://www.mpimet. mpg.de/fileadmin/publikationen/Reports/max_scirep_349.pdf (last access: 25 September 2017), 2003.

Rothrock, D. A., Percival, D. B., and Wensnahan, M.: The decline in arctic sea-ice thickness: Separating the spatial, annual, and interannual variability in a quarter century of submarine data, J. Geophys. Res.-Oceans, 113, 1-9, https://doi.org/10.1029/2007JC004252, 2008.

Sand, M., Berntsen, T. K., Seland, Ø., and Kristjánsson, J. E.: Arctic surface temperature change to emissions of black carbon within Arctic or midlatitudes, J. Geophys. Res.-Atmos., 118, 77887798, https://doi.org/10.1002/jgrd.50613, 2013a.

Sand, M., Berntsen, T. K., Kay, J. E., Lamarque, J. F., Seland, Ø., and Kirkevåg, A.: The Arctic response to remote and local forcing of black carbon, Atmos. Chem. Phys., 13, 211-224, https://doi.org/10.5194/acp-13-211-2013, 2013 b.

Sand, M., Berntsen, T. K., von Salzen, K., Flanner, M. G., Langner, J., and Victor, D. G.: Response of Arctic temperature to changes in emissions of short-lived climate forcers, Nat. Clim. Chang., 6, 1-5, https://doi.org/10.1038/nclimate2880, 2015.

Sand, M., Samset, B. H., Balkanski, Y., Bauer, S., Bellouin, N., Berntsen, T. K., Bian, H., Chin, M., Diehl, T., Easter, R., Ghan, S. J., Iversen, T., Kirkevåg, A., Lamarque, J.-F., Lin, G., Liu, X., Luo, G., Myhre, G., van Noije, T., Penner, J. E., Schulz, M., Seland, Ø., Skeie, R. B., Stier, P., Takemura, T., Tsigaridis, K., Yu, F., Zhang, K., and Zhang, H.: Aerosols at the Poles: An AeroCom Phase II multi-model evaluation, Atmos. Chem. Phys. Discuss., https://doi.org/10.5194/acp-2016-1120, in review, 2017.

Sato, K., Inoue, J., and Watanabe, M.: Influence of the Gulf Stream on the Barents Sea ice retreat and Eurasian coldness during early winter, Environ. Res. Lett., 9, 084009, https://doi.org/10.1088/1748-9326/9/8/084009, 2014.

Schultz, M. (Eds.): REanalysis of the TROpospheric chemical composition over the past 40 years: Final report, Berichte zur Erdsystemforschung, 48, https://doi.org/10.17617/2.994467, 2007.

Schultz, M. G., Heil, A., Hoelzemann, J. J., Spessa, A., Thonicke, K., Goldammer, J. G., Held, A. C., Pereira, J. M. C., and van Het Bolscher, M.: Global wildland fire emissions from 1960 to 2000, Global Biogeochem. Cy., 22, 1-17, https://doi.org/10.1029/2007GB003031, 2008.

Schwarz, J. P., Gao, R. S., Fahey, D. W., Thomson, D. S., Watts, L. A., Wilson, J. C., Reeves, J. M., Darbeheshti, M., Baumgardner, D. G., Kok, G. L., Chung, S. H., Schulz, M., Hendricks, J., Lauer, A., Ka, B., and Slowik, J. G.: Single-particle measurements of midlatitude black carbon and light-scattering aerosols from the boundary layer to the lower stratosphere, J. Geophys. Res.Atmos., 111, D16207, https://doi.org/10.1029/2006JD007076, 2006.

Screen, J. A. and Simmonds, I.: Exploring links between Arctic amplification and mid-latitude weather, Geophys. Res. Lett., 40, 16, https://doi.org/10.1002/GRL.50174, 2013.

Screen, J. A., Simmonds, I., Deser, C., and Tomas, R.: The atmospheric response to three decades of observed arctic sea ice loss, J. Climate, 26, 1230-1248, https://doi.org/10.1175/JCLI-D-12$00063.1,2013$. 
Semenov, V. A. and Latif, M.: Nonlinear winter atmospheric circulation response to Arctic sea ice concentration anomalies for different periods during 1966-2012, Environ. Res. Lett., 10, 054020, https://doi.org/10.1088/1748-9326/10/5/054020, 2015.

Sen, P. K.: Estimates of the Regression Coefficient Based on Kendall's Tau, J. Am. Stat. Assoc., 63, 1379-1389, https://doi.org/10.2307/2285891, 1968.

Serreze, M. C. and Barry, R. G.: Processes and impacts of Arctic amplification: A research synthesis, Global Planet. Change, 77, 85-96, https://doi.org/10.1016/j.gloplacha.2011.03.004, 2011.

Sharma, S., Andrews, E., Barrie, L. A., Ogren, J. A., and Lavoue, D.: Variations and sources of the equivalent black carbon in the high Arctic revealed by long-term observations at Alert and Barrow?: 1989-2003, J. Geophys. Res.-Atmos., 111, D14208, https://doi.org/10.1029/2005JD006581, 2006.

Sharma, S., Ishizawa, M., Chan, D., Lavoué, D., Andrews, E., Eleftheriadis, K., and Maksyutov, S.: 16-year simulation of Arctic black carbon?: Transport, source contribution, and sensitivity analysis on deposition, J. Geophys. Res.-Atmos., 118, 943-964, https://doi.org/10.1029/2012JD017774, 2013.

Shaw, G. E. and Stamnes, K.: ARCTIC HAZE: PERTURBATION OF THE POLAR RADIATION BUDGET*, Ann. N. Y. Acad. Sci., 338, 533-539, https://doi.org/10.1111/j.17496632.1980.tb17145.x, 1980.

Shindell, D. and Faluvegi, G.: Climate response to regional radiative forcing during the twentieth century, Nat. Geosci, 2, 294-300, https://doi.org/10.1038/ngeo473, 2009.

Shindell, D., Kuylenstierna, J. C. I., Vignati, E., van Dingenen, R., Amann, M., Klimont, Z., Anenberg, S. C., Muller, N., Janssens-Maenhout, G., Raes, F., Schwartz, J., Faluvegi, G., Pozzoli, L., Kupiainen, K., Hoglund-Isaksson, L., Emberson, L., Streets, D., Ramanathan, V., Hicks, K., Oanh, N. T. K., Milly, G., Williams, M., Demkine, V., and Fowler, D.: Simultaneously Mitigating Near-Term Climate Change and Improving Human Health and Food Security, Science, 335, 183-189, https://doi.org/10.1126/science.1210026, 2012.

Stier, P., Feichter, J., Kinne, S., Kloster, S., Vignati, E., Wilson, J., Ganzeveld, L., Tegen, I., Werner, M., Balkanski, Y., Schulz, M., Boucher, O., Minikin, A., and Petzold, A.: The aerosol-climate model ECHAM5-HAM, Atmos. Chem. Phys., 5, 1125-1156, https://doi.org/10.5194/acp-5-1125-2005, 2005.

Stohl, A.: Characteristics of atmospheric transport into the Arctic troposphere, J. Geophys. Res.-Atmos., 111, 1-17, https://doi.org/10.1029/2005JD006888, 2006.
Stohl, A., Klimont, Z., Eckhardt, S., Kupiainen, K., Shevchenko, V. P., Kopeikin, V. M., and Novigatsky, A. N.: Black carbon in the Arctic: the underestimated role of gas flaring and residential combustion emissions, Atmos. Chem. Phys., 13, 8833-8855, https://doi.org/10.5194/acp-13-8833-2013, 2013.

Tsigaridis, K., Daskalakis, N., Kanakidou, M., Adams, P. J., Artaxo, P., Bahadur, R., Balkanski, Y., Bauer, S. E., Bellouin, N., Benedetti, A., Bergman, T., Berntsen, T. K., Beukes, J. P., Bian, H., Carslaw, K. S., Chin, M., Curci, G., Diehl, T., Easter, R. C., Ghan, S. J., Gong, S. L., Hodzic, A., Hoyle, C. R., Iversen, T., Jathar, S., Jimenez, J. L., Kaiser, J. W., Kirkevåg, A., Koch, D., Kokkola, H., Lee, Y. H., Lin, G., Liu, X., Luo, G., Ma, X., Mann, G. W., Mihalopoulos, N., Morcrette, J.-J., Müller, J.-F., Myhre, G., Myriokefalitakis, S., Ng, N. L., O’Donnell, D., Penner, J. E., Pozzoli, L., Pringle, K. J., Russell, L. M., Schulz, M., Sciare, J., Seland, Ø., Shindell, D. T., Sillman, S., Skeie, R. B., Spracklen, D., Stavrakou, T., Steenrod, S. D., Takemura, T., Tiitta, P., Tilmes, S., Tost, H., van Noije, T., van Zyl, P. G., von Salzen, K., Yu, F., Wang, Z., Wang, Z., Zaveri, R. A., Zhang, H., Zhang, K., Zhang, Q., and Zhang, X.: The AeroCom evaluation and intercomparison of organic aerosol in global models, Atmos. Chem. Phys., 14, 10845-10895, https://doi.org/10.5194/acp-1410845-2014, 2014.

Uppala, S. M., KÅllberg, P. W., Simmons, A. J., Andrae, U., Bechtold, V. D. C., Fiorino, M., Gibson, J. K., Haseler, J., Hernandez, A., Kelly, G. A., Li, X., Onogi, K., Saarinen, S., Sokka, N., Allan, R. P., Andersson, E., Arpe, K., Balmaseda, M. A., Beljaars, A. C. M., Berg, L. Van De, Bidlot, J., Bormann, N., Caires, S., Chevallier, F., Dethof, A., Dragosavac, M., Fisher, M., Fuentes, M., Hagemann, S., Hólm, E., Hoskins, B. J., Isaksen, L., Janssen, P. A. E. M., Jenne, R., Mcnally, A. P., Mahfouf, J.-F., Morcrette, J.-J., Rayner, N. A., Saunders, R. W., Simon, P., Sterl, A., Trenberth, K. E., Untch, A., Vasiljevic, D., Viterbo, P., and Woollen, J.: The ERA-40 re-analysis, Q. J. R. Meteor. Soc., 131, 29613012, https://doi.org/10.1256/qj.04.176, 2005.

Yasunari, T. J., Koster, R. D., Lau, K. M., Aoki, T., Sud, Y. C., Yamazaki, T., Motoyoshi, H., and Kodama, Y.: Influence of dust and black carbon on the snow albedo in the NASA Goddard Earth Observing System version 5 land surface model, J. Geophys. Res.-Atmos., 116, 1-15, https://doi.org/10.1029/2010JD014861, 2011. 